\title{
OPEN Effects of exogenous silicon on maize seed germination and seedling growth
}

\author{
Yankun Sun, Jiaqi Xu, Xiangyang Miao, Xuesong Lin, Wanzhen Liu \& Hongyu Ren ${ }^{\bowtie}$
}

As the global population continues to increase, global food production needs to double by 2050 to meet the demand. Given the current status of the not expansion of cultivated land area, agronomic seedlings are complete, well-formed and strong, which is the basis of high crop yields. The aim of this experiment was to study the effects of seed germination and seedling growth in response to silicon (from water-soluble Si fertilizer). The effects of Si on the maize germination, seedling growth, chlorophyll contents, osmoprotectant contents, antioxidant enzyme activities, nonenzymatic antioxidant contents and stomatal characteristics were studied by soaking Xianyu 335 in solutions of different concentrations of $\operatorname{Si}\left(0,5,10,15,20\right.$, and $\left.25 \mathrm{~g} \cdot \mathrm{L}^{-1}\right)$. In this study, Si treatments significantly increased the seed germination and per-plant dry weight of seedlings $(P<0.05)$, and the optimal concentration was $15 \mathrm{~g} \cdot \mathrm{L}^{-1}$. As a result of the Si treatment of the seeds, the chlorophyll content, osmotic material accumulation and antioxidant defence system activity increased, reducing membrane system damage, reactive oxygen species contents, and stomatal aperture. The results suggested that $15 \mathrm{~g} \cdot \mathrm{L}^{-1} \mathrm{Si}$ significantly stimulated seed germination and promoted the growth of maize seedlings, laying a solid foundation for subsequent maize growth.

Maize, an annual herbaceous plant species, is one of the most important crop species and is a major source of feed and industrial raw materials ${ }^{1}$. Maize plays an important role in ensuring food security and social and economic stability. In recent years, due to the increasing frequency of extreme weather events, unstable yields and low quality of maize caused by seed germination problems in the cold regions of northern China have become an important hidden danger of China's food security ${ }^{2}$. Seeds are the result of survival mechanisms of plants and constitute the material basis for production. The growth status during seed germination directly affects the growth of plants ${ }^{3}$. The rapid germination of maize seeds after sowing leads to early-stage seedlings, homogeneous seedlings and robust seedlings, which constitutes the solid foundation for producing high-quality and high-yield of crops ${ }^{4}$.

As a basic element of animals and humans, $\mathrm{Si}$ is a beneficial but unnecessary element of higher plants ${ }^{4,5}$. Although the importance of Si to plants has not been shown, its beneficial role in promoting plant growth has been demonstrated in laboratory and field experiments ${ }^{6}$. Si can enhance seed vigor, increase seedling relative growth rates, increase seedling dry weight, and promote seedling cotyledon growth, laying a foundation for increasing yield and improving quality ${ }^{7-10}$.

$\mathrm{Si}$ is listed as the fourth element after nitrogen $(\mathrm{N})$, phosphorus $(\mathrm{P})$ and potassium $(\mathrm{K})$ in the international soil classification system. Although soils are rich in $\mathrm{Si}$, most $\mathrm{Si}$ cannot be fully absorbed by plants ${ }^{11}$. At present, there are two main types of Si fertilizer in China: citrate-soluble and water-soluble Si fertilizer. Citrate-soluble $\mathrm{Si}$ fertilizer is insoluble in water but soluble in acid; it can be absorbed by crops immediately after application. Citrate-soluble Si typically is a waste product of steel slag during steelmaking, fly ash, or ore through hightemperature calcination process, etc. However, because the raw material is mainly industrial waste and the manufacturing process is relatively simple; many toxic substances from industrial production remain in this type of fertilizer. Water-soluble Si fertilizer is soluble in water and can be directly absorbed and utilized by plants. It is synthesized by high-temperature chemical reactions from a complex production technique that is expensive and produces a relatively small amount ${ }^{12}$.

Si-50G and Si-60G are new water-soluble Si fertilizers synthesized by sol method. The Si-50G and Si-60G have been reported to increase the yield of rice, the state of soil Si and the soil available nutrient content under low temperature stress ${ }^{13,14}$. Although several studies have shown that Si treatment can promote rice growth, its effects on maize seed germination and growth are poorly understood. The objective of this work was to evaluate the effects of different concentrations of $\mathrm{Si}$ (from water-soluble Si fertilizer) on seed germination and seedling 


\begin{tabular}{|l|l|l|l|l|l|l|}
\hline Type & Concentration $\left(\mathbf{g} \cdot \mathbf{L}^{-1}\right)$ & GR (\%) & GP $(\%)$ & GI & VI & Si content $\left(\mathbf{m g} \cdot \mathbf{g}^{-1}\right)$ \\
\hline Control & 0 & $82.00 \pm 2.00 \mathrm{e}$ & $44.00 \pm 2.00 \mathrm{e}$ & $11.78 \pm 0.66 \mathrm{~d}$ & $9.36 \pm 0.77 \mathrm{~g}$ & $0 \pm 0 \mathrm{c}$ \\
\hline \multirow{5}{*}{ Si-50G } & 5 & $93.63 \pm 0.61 \mathrm{~b}$ & $50.00 \pm 3.33 \mathrm{~cd}$ & $16.75 \pm 0.36 \mathrm{~b}$ & $16.97 \pm 0.46 \mathrm{c}$ & $6.03 \pm 0.7 \mathrm{ab}$ \\
\cline { 2 - 7 } & 10 & $96.01 \pm 0.57 \mathrm{a}$ & $53.73 \pm 0.53 \mathrm{bc}$ & $16.99 \pm 0.82 \mathrm{~b}$ & $17.85 \pm 1.24 \mathrm{c}$ & $6.06 \pm 0.57 \mathrm{ab}$ \\
\cline { 2 - 7 } & 15 & $97.84 \pm 1.87 \mathrm{a}$ & $61.11 \pm 3.85 \mathrm{a}$ & $18.11 \pm 0.86 \mathrm{a}$ & $21.43 \pm 1.18 \mathrm{a}$ & $6.67 \pm 0.84 \mathrm{a}$ \\
\cline { 2 - 7 } & 20 & $97.06 \pm 0.67 \mathrm{a}$ & $57.78 \pm 1.92 \mathrm{ab}$ & $17.01 \pm 0.71 \mathrm{~b}$ & $19.26 \pm 0.52 \mathrm{~b}$ & $6.56 \pm 0.5 \mathrm{a}$ \\
\cline { 2 - 7 } & 25 & $88.89 \pm 2.22 \mathrm{c}$ & $44.00 \pm 2.65 \mathrm{e}$ & $13.07 \pm 0.49 \mathrm{c}$ & $12.93 \pm 0.51 \mathrm{e}$ & $5.76 \pm 0.52 \mathrm{ab}$ \\
\hline \multirow{5}{*}{ Si-60G } & 5 & $84.00 \pm 1.00 \mathrm{de}$ & $55.33 \pm 2.31 \mathrm{~b}$ & $13.62 \pm 0.78 \mathrm{c}$ & $11.37 \pm 0.68 \mathrm{f}$ & $5.4 \pm 0.31 \mathrm{bc}$ \\
\cline { 2 - 7 } & 10 & $88.00 \pm 2.00 \mathrm{c}$ & $60.00 \pm 2.00 \mathrm{a}$ & $13.63 \pm 0.19 \mathrm{c}$ & $13.36 \pm 0.02 \mathrm{de}$ & $5.75 \pm 0.78 \mathrm{ab}$ \\
\cline { 2 - 7 } & 15 & $90.33 \pm 0.58 \mathrm{c}$ & $60.67 \pm 1.53 \mathrm{a}$ & $13.85 \pm 0.16 \mathrm{c}$ & $14.33 \pm 0.25 \mathrm{~d}$ & $5.92 \pm 0.62 \mathrm{ab}$ \\
\cline { 2 - 7 } & 20 & $85.33 \pm 0.58 \mathrm{~d}$ & $49.33 \pm 2.08 \mathrm{~d}$ & $13.46 \pm 0.22 \mathrm{c}$ & $12.17 \pm 0.34 \mathrm{ef}$ & $5.87 \pm 1.02 \mathrm{ab}$ \\
\cline { 2 - 7 } & 25 & $76.67 \pm 1.53 \mathrm{f}$ & $42.22 \pm 1.92 \mathrm{e}$ & $11.62 \pm 0.39 \mathrm{~d}$ & $8.85 \pm 0.54 \mathrm{~g}$ & $4.74 \pm 0.52 \mathrm{c}$ \\
\hline
\end{tabular}

Table 1. Effects of the $\mathrm{Si}\left(5,10,15,20\right.$, and $\left.25 \mathrm{~g} \cdot \mathrm{L}^{-1}\right)$ on germination indices. The values represent the mean \pm SE $(n=5)$. Values with the same letters in the columns are not significantly different at $\mathrm{P}<0.05$.

\begin{tabular}{|c|c|c|c|c|c|c|c|c|}
\hline Type & $\begin{array}{l}\text { Concentration } \\
\left(\mathrm{g} \cdot \mathrm{L}^{-1}\right)\end{array}$ & Shoot height $/(\mathrm{cm})$ & Root length $(\mathrm{cm})$ & $\begin{array}{l}\text { Shoot fresh mass } \\
\left(\text { g.plant }{ }^{-1}\right)\end{array}$ & $\begin{array}{l}\text { Root fresh mass } \\
\left(\mathrm{g} \cdot \text { plant }^{-1}\right)\end{array}$ & $\begin{array}{l}\text { Shoot dry weight } \\
\left(\mathrm{g} \cdot \text { plant }^{-1}\right)\end{array}$ & $\begin{array}{l}\text { Root dry weight of } \\
\left(\text { g.plant }{ }^{-1}\right)\end{array}$ & \begin{tabular}{|l|} 
Si content \\
$\left(\mathrm{mg}^{-1} \mathrm{~g}^{-1}\right)$
\end{tabular} \\
\hline Control & 0 & $57.50 \pm 0.36 \mathrm{i}$ & $27.20 \pm 0.40 \mathrm{f}$ & $4.91 \pm 0.01 \mathrm{~h}$ & $2.58 \pm 0.01 \mathrm{f}$ & $0.48 \pm 0.01 \mathrm{f}$ & $0.32 \pm 0.01 \mathrm{~g}$ & $4.23 \pm 0.09 \mathrm{bc}$ \\
\hline \multirow{5}{*}{ Si-50G } & 5 & $65.47 \pm 0.31 \mathrm{~d}$ & $30.83 \pm 0.42 c$ & $6.21 \pm 0.07 \mathrm{e}$ & $3.48 \pm 0.26 \mathrm{~d}$ & $0.60 \pm 0.02 b$ & $0.42 \pm 0.01 \mathrm{e}$ & $4.35 \pm 0.05 \mathrm{ab}$ \\
\hline & 10 & $67.50 \pm 0.30 c$ & $31.83 \pm 0.06 \mathrm{~b}$ & $6.72 \pm 0.09 \mathrm{~cd}$ & $3.66 \pm 0.08 c$ & $0.62 \pm 0.01 \mathrm{~b}$ & $0.43 \pm 0.01 \mathrm{~d}$ & $4.36 \pm 0.06 \mathrm{a}$ \\
\hline & 15 & $70.53 \pm 0.31 \mathrm{a}$ & $33.43 \pm 0.32 \mathrm{a}$ & $7.46 \pm 0.15 a$ & $4.19 \pm 0.01 \mathrm{a}$ & $0.70 \pm 0.02 \mathrm{a}$ & $0.48 \pm 0.01 \mathrm{a}$ & $4.43 \pm 0.06 \mathrm{a}$ \\
\hline & 20 & $68.33 \pm 0.25 b$ & $31.80 \pm 0.70 \mathrm{~b}$ & $6.84 \pm 0.17 \mathrm{bc}$ & $3.68 \pm 0.10 c$ & $0.68 \pm 0.02 a$ & $0.45 \pm 0.01 b c$ & $4.40 \pm 0.06 a$ \\
\hline & 25 & $63.63 \pm 0.25 \mathrm{e}$ & $30.80 \pm 0.35 c$ & $5.89 \pm 0.23 \mathrm{f}$ & $3.34 \pm 0.05 \mathrm{~d}$ & $0.59 \pm 0.01 b$ & $0.40 \pm 0.01 \mathrm{f}$ & $4.34 \pm 0.06 \mathrm{ab}$ \\
\hline \multirow{5}{*}{$\mathrm{Si}-60 \mathrm{G}$} & 5 & $59.23 \pm 0.35 \mathrm{~h}$ & $29.47 \pm 0.31 d$ & $6.30 \pm 0.07 \mathrm{e}$ & $3.30 \pm 0.07 \mathrm{~d}$ & $0.50 \pm 0.02 \mathrm{e}$ & $0.33 \pm 0.01 \mathrm{~g}$ & $4.35 \pm 0.06 \mathrm{ab}$ \\
\hline & 10 & $60.50 \pm 0.30 \mathrm{~g}$ & $29.83 \pm 0.35 \mathrm{~d}$ & $6.47 \pm 0.36 \mathrm{de}$ & $3.42 \pm 0.03 \mathrm{~d}$ & $0.54 \pm 0.01 \mathrm{~d}$ & $0.44 \pm 0.01 \mathrm{~cd}$ & $4.35 \pm 0.06 \mathrm{ab}$ \\
\hline & 15 & $62.73 \pm 0.61 \mathrm{f}$ & $30.80 \pm 0.40 c$ & $7.12 \pm 0.27 b$ & $3.91 \pm 0.16 \mathrm{~b}$ & $0.57 \pm 0.01 \mathrm{c}$ & $0.47 \pm 0.01 \mathrm{ab}$ & $4.42 \pm 0.05 a$ \\
\hline & 20 & $59.40 \pm 0.35 \mathrm{~h}$ & $28.40 \pm 0.46 \mathrm{e}$ & $5.55 \pm 0.12 \mathrm{~g}$ & $2.78 \pm 0.06 \mathrm{e}$ & $0.50 \pm 0.01 \mathrm{ef}$ & $0.41 \pm 0.01 \mathrm{ef}$ & $4.37 \pm 0.07 \mathrm{a}$ \\
\hline & 25 & $52.30 \pm 0.46 \mathrm{j}$ & $26.53 \pm 0.31 \mathrm{f}$ & $4.80 \pm 0.14 \mathrm{~h}$ & $2.50 \pm 0.06 \mathrm{f}$ & $0.45 \pm 0.01 \mathrm{~g}$ & $0.32 \pm 0.01 \mathrm{~g}$ & $4.21 \pm 0.07 \mathrm{c}$ \\
\hline
\end{tabular}

Table 2. Effects of $\mathrm{Si}\left(5,10,15,20\right.$, and $\left.25 \mathrm{~g} \cdot \mathrm{L}^{-1}\right)$ on seedling growth. The values represent the mean $\pm \mathrm{SE}$ $(\mathrm{n}=4)$. Values with the same letters in the columns are not significantly different at $\mathrm{P}<0.05$.

growth. The reaction was evaluated on the basis of the germination index, growth index, chlorophyll content, peroxidase content, antioxidant enzyme activity, non-enzymatic antioxidant content and stomatal characteristics. With this information, we can better understand the possible mechanisms by which Si promotes maize seed germination and seedling growth to select the best type and concentration, providing a scientific basis for Si application in maize production.

\section{Results}

Effects of Si on the germination indices. As shown in Table 1, the Si-50G treatments $\left(5 \sim 25 \mathrm{~g} \cdot \mathrm{L}^{-1}\right)$ and the Si-60G treatments $\left(5 \sim 20 \mathrm{~g} \cdot \mathrm{L}^{-1}\right)$ could promote the germination of maize seeds, resulting in GR, GP, GI and VI values that were higher than those in the control group. However, Si-60G application decreased the GR, GI and VI in the $25 \mathrm{~g} \cdot \mathrm{L}^{-1}$ treatments. Compared to those of the control, the GR, GP, GI and VI under a concentration of $15 \mathrm{~g} \cdot \mathrm{L}^{-1}(\mathrm{Si}-50 \mathrm{G})$ markedly increased by $19.32 \%, 38.89 \%, 53.70 \%$ and $129.01 \%$, respectively $(\mathrm{P}<0.01)$. With the increase of concentration, the content of Si first increased but then decreased, and the effects were the most obvious at the concentration of $15 \mathrm{~g} \cdot \mathrm{L}^{-1}$.

Effects of Si on seedling growth. With the increase of concentration, the growth indices of the seedlings first increased but then decreased, and the effects were the most obvious at the concentration of $15 \mathrm{~g} \cdot \mathrm{L}^{-1}$ (Table 2). Compared with those of the control, the shoot height, root height, shoot fresh weight, root fresh weight, shoot dry weight, root dry weight under Si-50G $15 \mathrm{~g} \cdot \mathrm{L}^{-1}$ increased by $22.66 \%, 22.90 \%, 51.93 \%, 62.40 \%$, $45.83 \%$, and $50.00 \%$, respectively; furthermore, compared with those of the control, increased by $9.10 \%, 13.24 \%$, $45.01 \%, 51.55 \%, 18.75 \%$ and $46.88 \%$ under the Si-60G $15 \mathrm{~g} \cdot \mathrm{L}^{-1}$, respectively. Moreover, compared with those of the control, the shoot height, root height, shoot fresh weight, root fresh weight, shoot dry weight under the Si-60G $25 \mathrm{~g} \cdot \mathrm{L}^{-1}$ decreased by $9.04 \%, 2.46 \%, 2.24 \%, 3.10 \%$ and $6.25 \%$, respectively. Compared with that of the control, the Si content under $15 \mathrm{~g} \cdot \mathrm{L}^{-1}$ increased by $4.69 \%$ and $4.38 \%(\mathrm{P}<0.01)$.

Effects of Si on the photosynthetic pigment contents. The Si-50G treatments $\left(5 \sim 25 \mathrm{~g} \cdot \mathrm{L}^{-1}\right) \mathrm{mark}-$ edly increased the Chl $a+b$ content, the Chl $a$ content, the Chl $b$ content, and the Car content by $0.92 \% \sim 6.81 \%$, 


\begin{tabular}{|c|c|c|c|c|c|}
\hline Type & Concentration $\left(\mathrm{g} \cdot \mathrm{L}^{-1}\right)$ & $\mathrm{Chl} \mathbf{a}+\mathbf{b}\left(\mathrm{mg} \cdot \mathrm{g}^{-1} \mathrm{FW}\right)$ & $C h l$ a $\left(\mathrm{mg} \cdot \mathrm{g}^{-1} \mathrm{FW}\right)$ & Chl b $\left(\mathrm{mg} \cdot \mathrm{g}^{-1} \mathrm{FW}\right)$ & $\operatorname{Car}\left(\mathrm{mg} \cdot \mathrm{g}^{-1} \mathrm{FW}\right)$ \\
\hline Control & 0 & $5.24 \pm 0.06 \mathrm{~cd}$ & $2.81 \pm 0.05 \mathrm{~cd}$ & $2.43 \pm 0.11 b c$ & $1.36 \pm 0.06 \mathrm{de}$ \\
\hline \multirow{5}{*}{$\mathrm{Si}-50 \mathrm{G}$} & 5 & $5.33 \pm 0.18 \mathrm{bc}$ & $2.87 \pm 0.07 \mathrm{abcd}$ & $2.46 \pm 0.13 \mathrm{bc}$ & $1.40 \pm 0.02 \mathrm{~cd}$ \\
\hline & 10 & $5.37 \pm 0.11 b c$ & $2.91 \pm 0.08 \mathrm{abc}$ & $2.46 \pm 0.08 \mathrm{bc}$ & $1.44 \pm 0.01 \mathrm{abc}$ \\
\hline & 15 & $5.60 \pm 0.03 \mathrm{a}$ & $2.97 \pm 0.07 \mathrm{a}$ & $2.63 \pm 0.07 \mathrm{a}$ & $1.46 \pm 0.03 \mathrm{a}$ \\
\hline & 20 & $5.49 \pm 0.10 \mathrm{ab}$ & $2.95 \pm 0.04 \mathrm{a}$ & $2.53 \pm 0.11 \mathrm{ab}$ & $1.45 \pm 0.01 \mathrm{ab}$ \\
\hline & 25 & $5.29 \pm 0.08 \mathrm{~cd}$ & $2.86 \pm 0.06 \mathrm{abcd}$ & $2.44 \pm 0.09 \mathrm{bc}$ & $1.40 \pm 0.01 \mathrm{bcd}$ \\
\hline \multirow{5}{*}{$\mathrm{Si}-60 \mathrm{G}$} & 5 & $5.26 \pm 0.03 \mathrm{~cd}$ & $2.81 \pm 0.05 \mathrm{bcd}$ & $2.43 \pm 0.06 \mathrm{bc}$ & $1.40 \pm 0.01 \mathrm{~cd}$ \\
\hline & 10 & $5.37 \pm 0.12 \mathrm{bc}$ & $2.91 \pm 0.06 \mathrm{abc}$ & $2.46 \pm 0.05 b c$ & $1.42 \pm 0.02 \mathrm{abc}$ \\
\hline & 15 & $5.42 \pm 0.06 \mathrm{bc}$ & $2.94 \pm 0.07 \mathrm{ab}$ & $2.48 \pm 0.02 \mathrm{bc}$ & $1.44 \pm 0.01 \mathrm{abc}$ \\
\hline & 20 & $5.30 \pm 0.06 \mathrm{~cd}$ & $2.86 \pm 0.07 \mathrm{abcd}$ & $2.44 \pm 0.03 \mathrm{bc}$ & $1.43 \pm 0.01 \mathrm{abc}$ \\
\hline & 25 & $5.14 \pm 0.08 \mathrm{~d}$ & $2.78 \pm 0.04 \mathrm{~d}$ & $2.36 \pm 0.04 \mathrm{c}$ & $1.33 \pm 0.04 \mathrm{e}$ \\
\hline
\end{tabular}

Table 3. Effects of $\mathrm{Si}\left(5,10,15,20\right.$, and $\left.25 \mathrm{~g} \cdot \mathrm{L}^{-1}\right)$ on the photosynthetic pigment contents. The values represent the mean $\pm S E(n=4)$. Values with the same letters in the columns are not significantly different at $\mathrm{P}<0.05$.

\begin{tabular}{|l|l|l|l|l|}
\hline Type & Concentration $\left(\mathbf{g} \cdot \mathbf{L}^{-\mathbf{1}}\right)$ & Sugar content $\left(\mathbf{m g} \cdot \mathbf{g}^{-\mathbf{1}} \mathbf{F W}\right)$ & Protein content $\left(\mathbf{m g} \cdot \mathbf{g}^{-1} \mathbf{F W}\right)$ & Proline content $\left(\boldsymbol{\mu g} \cdot \mathbf{g}^{-\mathbf{1}} \mathbf{F W}\right)$ \\
\hline CK & 0 & $4.06 \pm 0.09 \mathrm{f}$ & $2.26 \pm 0.04 \mathrm{~h}$ & $3.08 \pm 0.13 \mathrm{e}$ \\
\hline \multirow{5}{*}{ Si-50G } & 5 & $4.27 \pm 0.04 \mathrm{e}$ & $2.53 \pm 0.08 \mathrm{f}$ & $3.34 \pm 0.03 \mathrm{~d}$ \\
\cline { 2 - 5 } & 10 & $4.33 \pm 0.03 \mathrm{de}$ & $2.63 \pm 0.08 \mathrm{de}$ & $3.70 \pm 0.06 \mathrm{~d}$ \\
\cline { 2 - 5 } & 15 & $5.03 \pm 0.03 \mathrm{a}$ & $3.03 \pm 0.04 \mathrm{a}$ & $3.92 \pm 0.03 \mathrm{a}$ \\
\cline { 2 - 5 } & 20 & $4.44 \pm 0.07 \mathrm{~d}$ & $2.88 \pm 0.06 \mathrm{~b}$ & $3.33 \pm 0.09 \mathrm{~d}$ \\
\cline { 2 - 5 } & 25 & $4.26 \pm 0.04 \mathrm{e}$ & $2.40 \pm 0.08 \mathrm{~g}$ & $3.24 \pm 0.03 \mathrm{~d}$ \\
\hline \multirow{5}{*}{ Si-60G } & 5 & $4.26 \pm 0.03 \mathrm{e}$ & $2.55 \pm 0.04 \mathrm{ef}$ & $3.31 \pm 0.08 \mathrm{~d}$ \\
\cline { 2 - 5 } & 10 & $4.85 \pm 0.04 \mathrm{bc}$ & $2.77 \pm 0.02 \mathrm{c}$ & $3.62 \pm 0.01 \mathrm{~b}$ \\
\cline { 2 - 5 } & 20 & $4.90 \pm 0.07 \mathrm{ab}$ & $2.97 \pm 0.06 \mathrm{ab}$ & $3.70 \pm 0.03 \mathrm{~b}$ \\
\cline { 2 - 5 } & 25 & $4.73 \pm 0.24 \mathrm{c}$ & $2.67 \pm 0.066^{\star} \mathrm{d}$ & $3.49 \pm 0.01 \mathrm{c}$ \\
\hline
\end{tabular}

Table 4. Effects of $\mathrm{Si}\left(5,10,15,20\right.$, and $\left.25 \mathrm{~g} \cdot \mathrm{L}^{-1}\right)$ on on the contents of osmolytes (sugar, protein and proline). The values represent the mean $\pm S E(n=4)$. Values with the same letters in the columns are not significantly different at $\mathrm{P}<0.05$.

$1.49 \% \sim 5.58 \%, 0.29 \% \sim 8.27 \%$, and 3.09\% 6.99\%, respectively (Table 3). The Si-60G treatments $\left(5 \sim 20\right.$ g. $\left.\mathrm{L}^{-1}\right)$ markedly increased the Chl $a+b$ content, the Chl $a$ content, the Chl $b$ content, and the Car content by $0.27 \% \sim 3.30 \%, 0.60 \% \sim 4.48 \%, 0.29 \% \sim 1.98 \%$, and $2.87 \% \sim 5.88 \%$, respectively. Compared with those of control, Chl $a+b$, Chl $a$, Chl $b$ and Car contents under the Si-60G $25 \mathrm{~g} \cdot \mathrm{L}^{-1}$ decreased by $1.91 \%, 1.42 \%, 2.88 \%$ and $2.21 \%$, respectively.

Effects of Si on osmolyte contents. As shown in Table 4, except for the sugar and proline contents under the Si-60G $25 \mathrm{~g} \cdot \mathrm{L}^{-1}$, the soluble sugar, soluble protein and proline contents in maize leaves significantly increased with $\mathrm{Si}$ application compared with the control $(\mathrm{P}<0.05)$. Compared with those of the control, the soluble sugar, soluble protein and proline contents under the Si-50G at $15 \mathrm{~g} \cdot \mathrm{L}^{-1}$ significantly increased by $23.89 \%, 34.07 \%$ and $27.27 \%$, respectively $(\mathrm{P}<0.01)$; furthermore, compared with those of the control, the same parameters under the Si-60G at $15 \mathrm{~g} \cdot \mathrm{L}^{-1}$ increased by $20.69 \%, 31.42 \%$ and $20.13 \%$, respectively $(\mathrm{P}<0.01)$. However, the soluble sugar and proline contents decreased by $2.46 \%$ and $1.32 \%$, respectively, and the soluble protein contents significantly decreased by $5.75 \%$ compared with the control values.

Effects of Si on reactive oxygen species. Si reduced the generation rate of $\mathrm{O}_{2}{ }^{--}$and $\mathrm{H}_{2} \mathrm{O}_{2}$ content in seedlings, and the effects were more pronounced under $15 \mathrm{~g} \cdot \mathrm{L}^{-1}$ (Fig. 1a,b). Compared with the control values, the Si-50G treatments decreased the generation rate of $\mathrm{O}_{2}{ }^{--}$by $2.90 \%, 5.20 \%, 8.50 \%, 6.28 \%$ and $5.67 \%$ and decreased the $\mathrm{H}_{2} \mathrm{O}_{2}$ content by $5.90 \%, 7.41 \%, 9.70 \%, 8.20 \%$ and $4.63 \%$, respectively. Moreover, the Si-60G at $5 \sim 20 \mathrm{~g} \cdot \mathrm{L}^{-1}$ treatments decreased the generation rate of $\mathrm{O}_{2}^{-}$by $2.19 \%, 4.29 \%, 6.38 \%$ and $3.04 \%$, respectively, and decreased the $\mathrm{H}_{2} \mathrm{O}_{2}$ content by $4.23 \%, 5.61 \%, 8.58 \%$ and $5.98 \%$, respectively. However, the Si-60G at $25 \mathrm{~g} \cdot \mathrm{L}^{-1}$ treatment increased the generation rate of $\mathrm{O}_{2}{ }^{--}$and the $\mathrm{H}_{2} \mathrm{O}_{2}$ content by $0.94 \%$ and $2.70 \%$, respectively.

Effects of Si on lipid peroxidation. The non-Si-treated maize seedlings had a higher membrane permeability and MDA content. However, these parameters nearly significantly decreased compared with those of the control when Si was present. Compared with those of the control, the MDA content and EL under the Si-50G 

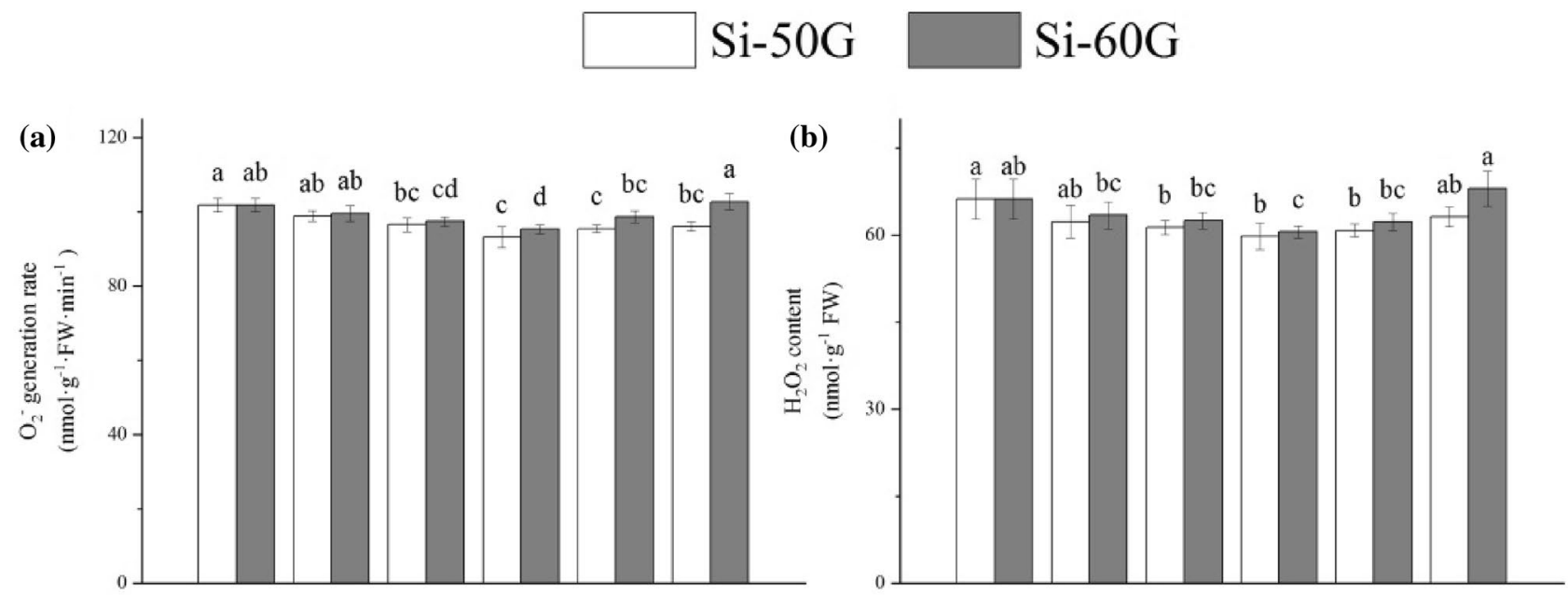

(c)
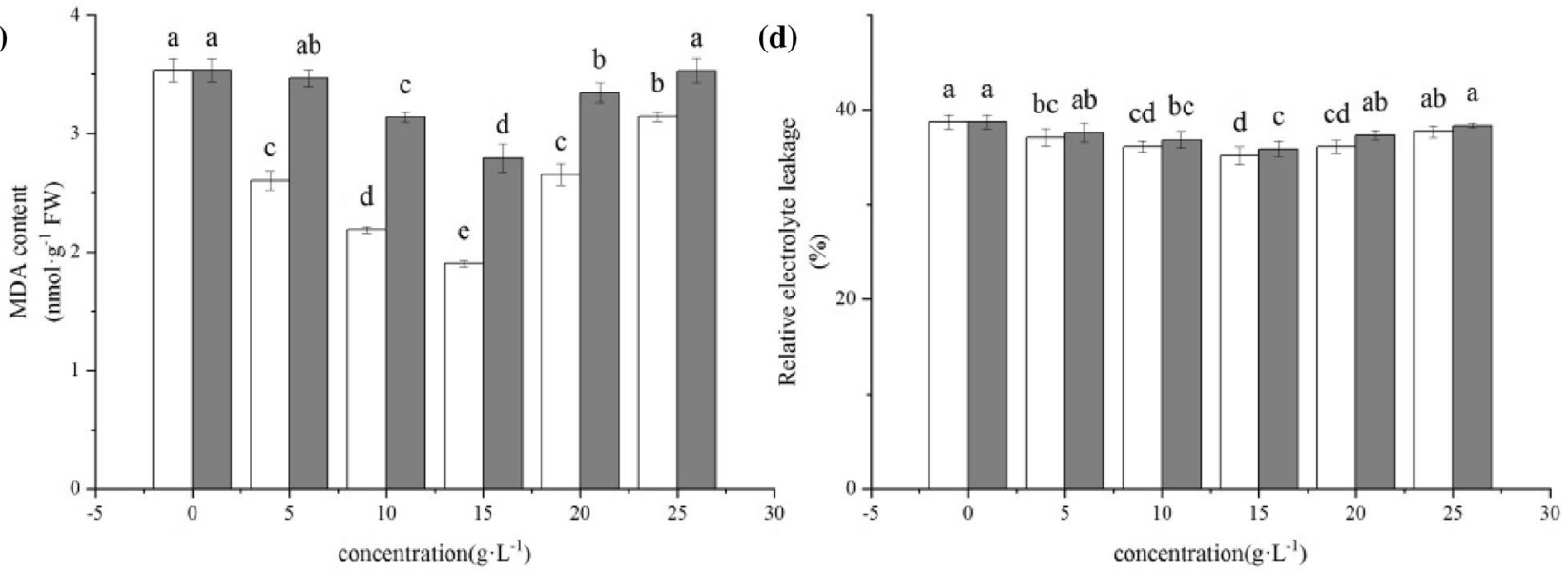

Figure 1. Effects of $\mathrm{Si}\left(5,10,15,20\right.$, and $\left.25 \mathrm{~g} \cdot \mathrm{L}^{-1}\right)$ on ROS and lipid peroxidation. The values represent the mean $\pm S E(n=4)$. Mean values provided with error bars representing the standard error. Different letters denote statistical differences at $\mathrm{P}<0.05$.

$15 \mathrm{~g} \cdot \mathrm{L}^{-1}$ significantly decreased by $46.17 \%$ and $20.93 \%$ (Fig. $1 \mathrm{c}$ ) and by $9.17 \%$ and $7.36 \%$ under the $\mathrm{Si}-60 \mathrm{G}$ 15 g. $\mathrm{L}^{-1}$ (Fig. 1d), respectively $(\mathrm{P}<0.01)$.

Effects of Si on antioxidant enzyme activities. Compared with those of the control, the activities of SOD, POD, CAT and APX in the leaves in response to Si application increased, and the GR activity decreased (Fig. 2). Compared with that of the controls, the SOD, POD, CAT and APX increased by $16.16 \%, 12.08 \%, 18.73 \%$ and $15.38 \%$, respectively, and by $31.31 \%$ and $27.89 \%, 21.31 \%$ and $20.06 \%$, respectively at the 15 g.L $\mathrm{L}^{-1}(\mathrm{P}<0.01)$. However, compared with that of the control, the GR activity was decreased by $32.21 \%$ and $18.12 \%$, respectively at the $15 \mathrm{~g} \cdot \mathrm{L}^{-1}(\mathrm{P}<0.01)$ (Fig. 2e).

Effects of Si on non-enzymatic antioxidant contents. Compared with those of the control, the GSH and AsA contents under Si-50G at 15 g. $\mathrm{L}^{-1}$ clearly increased by $28.05 \%$ and $18.29 \%$, respectively (Fig. $3 \mathrm{a}$ ); furthermore, compared with those of the control, the same parameters in the Si-60G at $15 \mathrm{~g} \cdot \mathrm{L}^{-1}$ treatment group increased by $16.46 \%$ and $13.50 \%$, respectively $(\mathrm{P}<0.01)$ (Fig. $3 \mathrm{~b})$.

Effects of Si on stomatal size and aperture. The size of stomatal notably changed. With the increasing $\mathrm{Si}$ concentration, the length and width of the stomata and the stomatal aperture first increased but then decreased. However, with the increasing concentration, the width of stomatal aperture first decreased but then increased. In addition, under the $15 \mathrm{~g} \cdot \mathrm{L}^{-1}$, the width of stomatal aperture significantly decreased by $24.34 \%$ and $17.11 \%(\mathrm{P}<0.01)$, respectively, compared with those of the control (Table 5).

\section{Discussion}

The GR, GP, GI and VI of seeds are important indicators to measure the germination performance of plant seed $s^{15}$. Seed germination and seedling emergence are the most critical and sensitive stages in plant life cycle. The results of this study show that the Si-50G treatments $\left(5 \sim 25 \mathrm{~g} \cdot \mathrm{L}^{-1}\right)$ and the Si-60G treatments $\left(5 \sim 20 \mathrm{~g} \cdot \mathrm{L}^{-1}\right)$ 
(a)

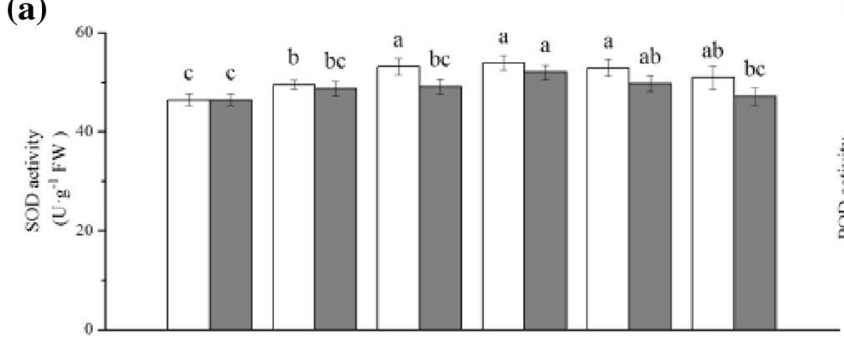

(b)

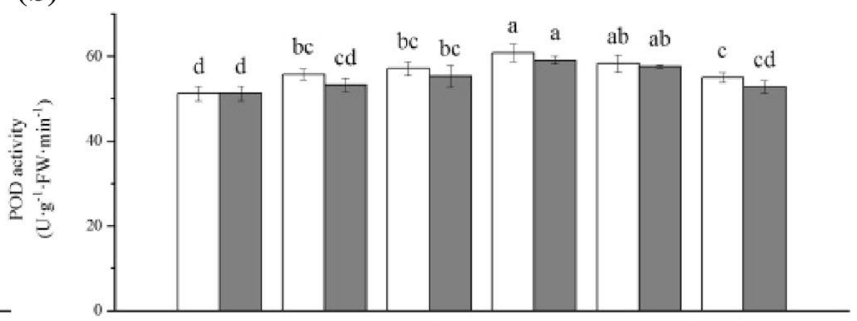

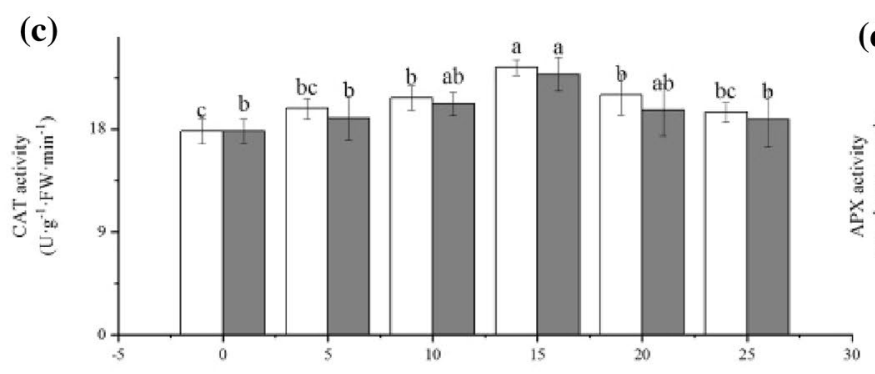

(d)
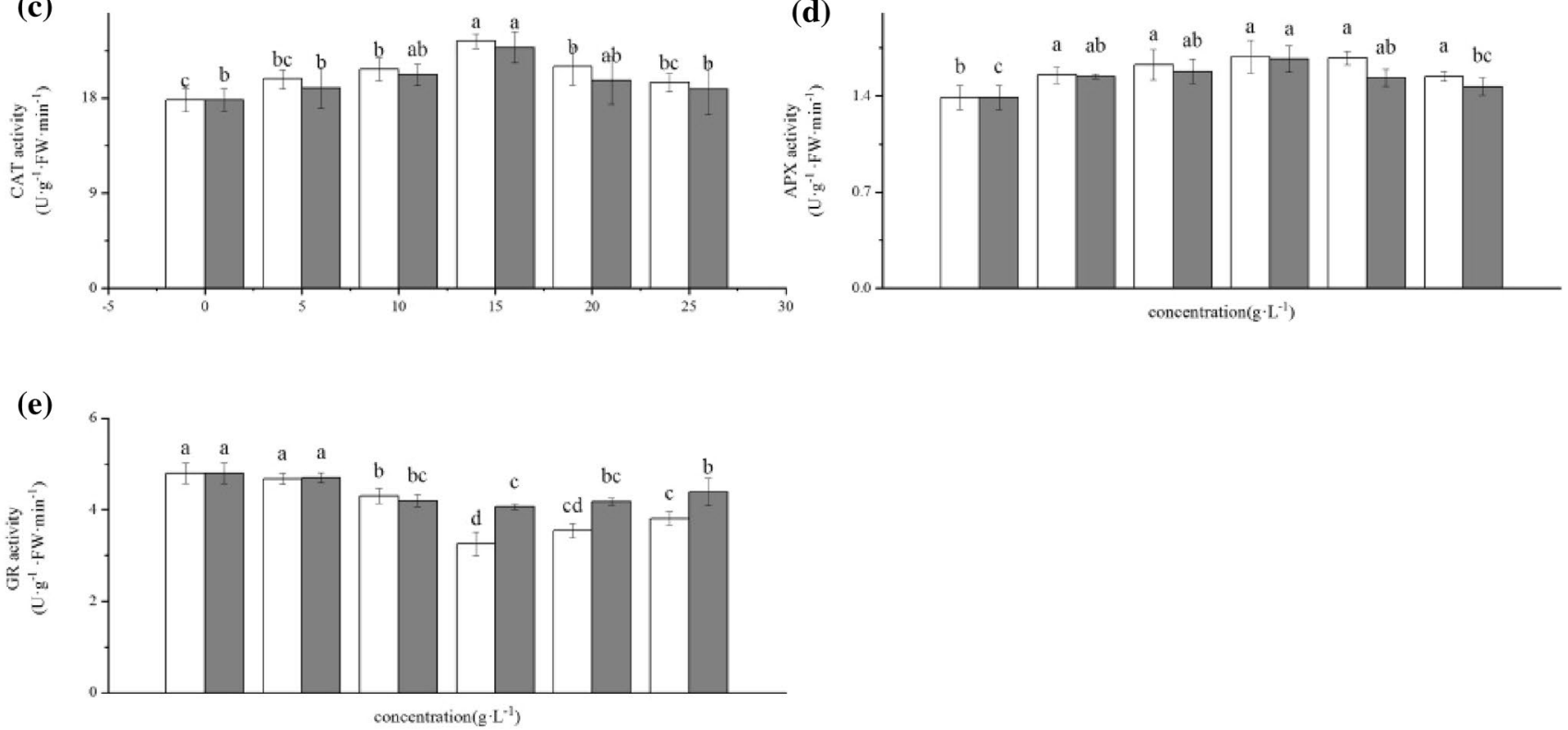

Figure 2. Effects of $\mathrm{Si}\left(5,10,15,20\right.$, and $\left.25 \mathrm{~g} \cdot \mathrm{L}^{-1}\right)$ on antioxidant enzyme activities. The values represent the mean $\pm \operatorname{SE}(n=4)$. Mean values provided with error bars representing the standard error. Different letters denote statistical differences at $\mathrm{P}<0.05$.
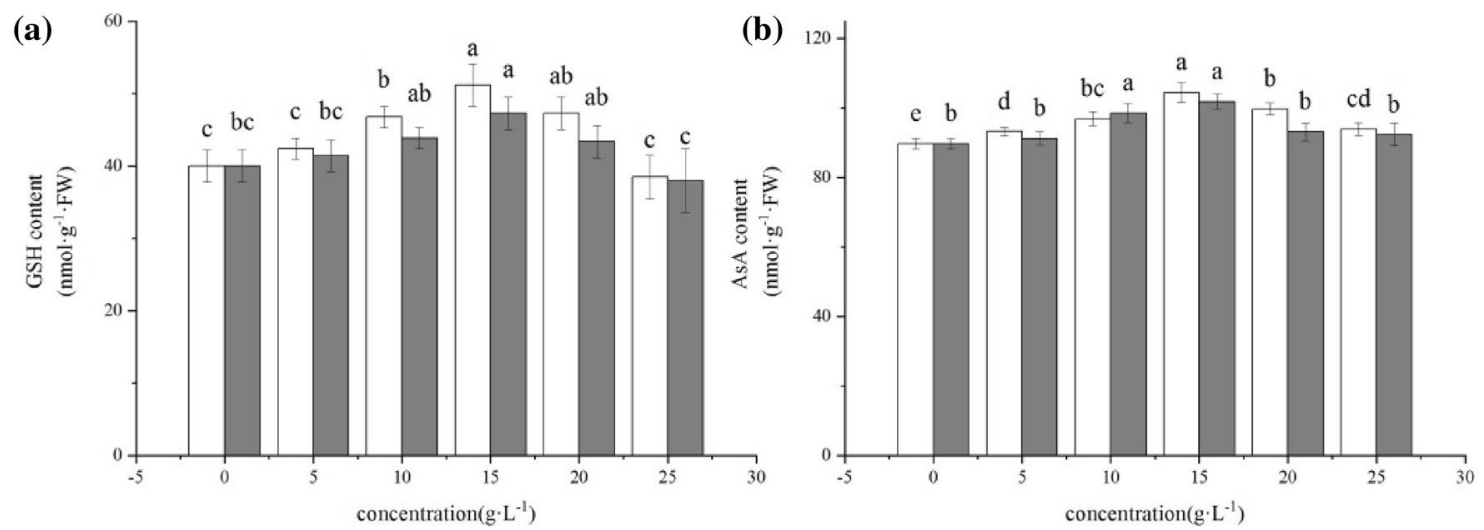

Figure 3. Effects of $\mathrm{Si}\left(5,10,15,20\right.$, and $\left.25 \mathrm{~g} \cdot \mathrm{L}^{-1}\right)$ on on non-enzymatic antioxidant contents. The values represent the mean $\pm S E(n=4)$. Mean values provided with error bars representing the standard error. Different letters denote statistical differences at $\mathrm{P}<0.05$. 


\begin{tabular}{|c|c|c|c|c|c|}
\hline \multirow[b]{2}{*}{ Type } & \multirow[b]{2}{*}{ Concentration $\left(\mathrm{g} \cdot \mathrm{L}^{-1}\right)$} & \multicolumn{2}{|c|}{ Stomatal size $(\mu \mathrm{m})$} & \multicolumn{2}{|c|}{ Stomatal aperture $(\mu \mathrm{m})$} \\
\hline & & Length & Width & Length & Width \\
\hline Control & 0 & $30.73 \pm 0.25 f$ & $22.90 \pm 0.70 \mathrm{ab}$ & $17.50 \pm 0.10 \mathrm{~g}$ & $1.52 \pm 0.02 \mathrm{a}$ \\
\hline \multirow{5}{*}{$\mathrm{Si}-50 \mathrm{G}$} & 5 & $28.33 \pm 0.21 \mathrm{~g}$ & $16.00 \pm 0.20 \mathrm{f}$ & $17.97 \pm 0.29 \mathrm{~g}$ & $1.32 \pm 0.03 \mathrm{bc}$ \\
\hline & 10 & $28.97 \pm 0.45 \mathrm{~g}$ & $19.07 \pm 0.51 \mathrm{e}$ & $19.30 \pm 0.10 \mathrm{f}$ & $1.26 \pm 0.06 c$ \\
\hline & 15 & $36.30 \pm 0.70 c$ & $23.33 \pm 0.65 a$ & $27.43 \pm 0.12 \mathrm{a}$ & $1.15 \pm 0.05 \mathrm{~d}$ \\
\hline & 20 & $34.77 \pm 0.31 \mathrm{~d}$ & $21.67 \pm 1.10 \mathrm{bc}$ & $22.60 \pm 0.26 \mathrm{c}$ & $1.30 \pm 0.03 \mathrm{bc}$ \\
\hline & 25 & $30.97 \pm 0.40 \mathrm{f}$ & $21.47 \pm 0.91 \mathrm{~cd}$ & $20.23 \pm 0.47 \mathrm{e}$ & $0.79 \pm 0.03 \mathrm{e}$ \\
\hline \multirow{5}{*}{ Si-60G } & 5 & $34.23 \pm 0.50 \mathrm{~d}$ & $20.03 \pm 0.40 \mathrm{e}$ & $19.90 \pm 0.01 \mathrm{ef}$ & $1.38 \pm 0.05 \mathrm{~b}$ \\
\hline & 10 & $38.30 \pm 0.17 \mathrm{~b}$ & $20.30 \pm 0.86 \mathrm{de}$ & $21.80 \pm 0.89 \mathrm{~d}$ & $1.35 \pm 0.10 \mathrm{bc}$ \\
\hline & 15 & $40.50 \pm 0.30 \mathrm{a}$ & $23.70 \pm 0.90 \mathrm{a}$ & $23.70 \pm 0.35 b$ & $1.26 \pm 0.04 \mathrm{c}$ \\
\hline & 20 & $34.40 \pm 0.26 \mathrm{~d}$ & $19.57 \pm 0.81 \mathrm{e}$ & $22.73 \pm 0.68 \mathrm{c}$ & $1.32 \pm 0.08 \mathrm{bc}$ \\
\hline & 25 & $33.43 \pm 0.25 \mathrm{e}$ & $13.77 \pm 0.49 \mathrm{~g}$ & $19.70 \pm 0.66 \mathrm{ef}$ & $0.70 \pm 0.01 \mathrm{f}$ \\
\hline
\end{tabular}

Table 5. Effects of $\mathrm{Si}\left(5,10,15,20\right.$ or $\left.25 \mathrm{~g} \cdot \mathrm{L}^{-1}\right)$ on stomatal size and aperture. The values represent the mean \pm SE $(n=4)$. Values with the same letters in the columns are not significantly different at $\mathrm{P}<0.05$.

could significantly improve the GR, GP, GI and VI of maize seeds (Table 1). This indicates that the appropriate concentration of Si can help maize seeds break dormancy, accelerate the restoration of seed vigor and recovery from damage when drying seeds, complete the germination and emergence process, and provide better physiological conditions for subsequently seedling growth ${ }^{2}$.

Exogenous Si can promote the growth of soybean ${ }^{16}$, barley ${ }^{17}$ and seedlings of other species. Moreover, exogenous Si can increase the root length and seedling height and can increase the fresh and dry weight of seedlings. In this study, most of the Si treatments enhanced the height, length and dry weight of maize seedlings (Table 2). The highest germination percentage was obtained under the Si-50G at $15 \mathrm{~g} \cdot \mathrm{L}^{-1}$, and the total dry and fresh weight of seedlings significantly increased. The effects of $15 \mathrm{~g} \cdot \mathrm{L}^{-1} \mathrm{Si}$ on the maize root system was better than that on the whole plants. The establishment of seedlings after seed germination is the period that is most sensitive to the external environment. A healthy and intact root system can ensure that plants can absorb sufficient amounts of water, nutrients and mineral ions from the soil and promote photosynthesis of plant leaves to complete self-growth ${ }^{2}$.

$C h l a$ and $C h l b$ are the main pigments that absorb and transmit light energy, which can improve the efficiency of light capture ${ }^{18}$. Car is photosynthetic pigment that absorbs light energy and transmits it to the reaction centers. Our results suggested that by $15 \mathrm{~g} \cdot \mathrm{L}^{-1} \mathrm{Si}$ could increase the contents of Chl $a+b$, Chl $a$, Chl $b$ and Car (Table 3). The application of Si may be associated with an increase in chlorophyll content, which may be because Si can eventually enter into the chloroplast through plant absorption and transport, increasing the chlorophyll content of the plant and thus increasing photosynthesis ${ }^{19,20}$. However, the Si-60G at $25 \mathrm{~g} \cdot \mathrm{L}^{-1}$ reduced the contents of Chl $a+b$, Chl $a$, Chl $b$ and Car in maize seedlings. This may be due to the excessive concentration of $\mathrm{Si}$, which reduces chlorophyll synthesis, while a decrease of soluble sugar content both inhibits stomatal opening and normal photosynthesis ${ }^{21}$.

As osmotic regulators, soluble sugar and proline can effectively reduce the osmotic potential of plant cells by increasing its content $\mathrm{t}^{22,23}$. The osmotic function of soluble protein is well $\mathrm{known}^{24}$. Si increased the content of soluble sugar, soluble protein and proline in maize seedlings (Table 4) and decreased the cell fluid osmotic potential (Fig. 2d), indicating that Si could play an important regulatory role in maintaining normal cell metabolism. In addition, according to the above experiments, Si can promote the synthesis of soluble sugar, soluble protein and proline, maintain its contents at a high level, and increase the ability of osmotic regulatory ability of seedlings. With applications of $\mathrm{Si}$, the increase in these permeable substances may be an effective mechanism to improve the ability of plants to resist oxidative stress ${ }^{25}$.

Under adverse conditions, plants produce an excess amount of reactive oxygen species (ROS) ${ }^{26}$, which can cause membrane peroxidation and electrolyte leakage in cells, eventually destroying the structure and function of the cell membrane ${ }^{27-29}$. However, the protective system of the organisms can remove these ROS and reduce harm. SOD, POD, CAT, APX and GR are the main enzymes involved in the protection system, and these enzymes play a key role in enhancing plant stress resistance and maintaining normal plant growth, metabolism and development ${ }^{30}$. Changes in the activities of these enzymes reflect the protective response of plants. SOD is a purifier of $\mathrm{O}_{2}{ }^{--}$and protects cells by removing $\mathrm{O}_{2}{ }^{--}$and reducing the concentration of other reactive oxygen species produced by $\mathrm{O}_{2}{ }^{--}$. POD is a protective enzyme with high activity that is widely present in plants; it plays an important role in cell metabolism. The increase in POD activity is beneficial to plant growth and development ${ }^{31}$. CAT can remove $\mathrm{H}_{2} \mathrm{O}_{2}$ produced by stress in plants and decompose the accumulated $\mathrm{H}_{2} \mathrm{O}_{2}$ into $\mathrm{H}_{2} \mathrm{O}$ and $\mathrm{O}_{2}$, thus reducing its ability to damage plant tissues oxidatively ${ }^{32}$. The enzymatic antioxidants APX and GR, as well as nonenzymatic antioxidants AsA and GSH, are important components to eliminate ROS and reduce oxidative damage under abiotic stress ${ }^{33}$. These antioxidants have their own functions and maintain the redox state of cells ${ }^{34,35}$. In this study, the appropriate concentration of Si could enhance the activity of SOD, POD, CAT and APX and the content of AsA and GSH; reduce the content of MDA; effectively enhance the ROS-scavenging ability of plants to maintain the balance of ROS metabolism; reduce oxidative stress reactions; and reduce the degree of cell EL, thus promoting the growth of maize ${ }^{10,36}$. However, the Si-60G at $25 \mathrm{~g} \cdot \mathrm{L}^{-1}$ treatment resulted in an increase in the 

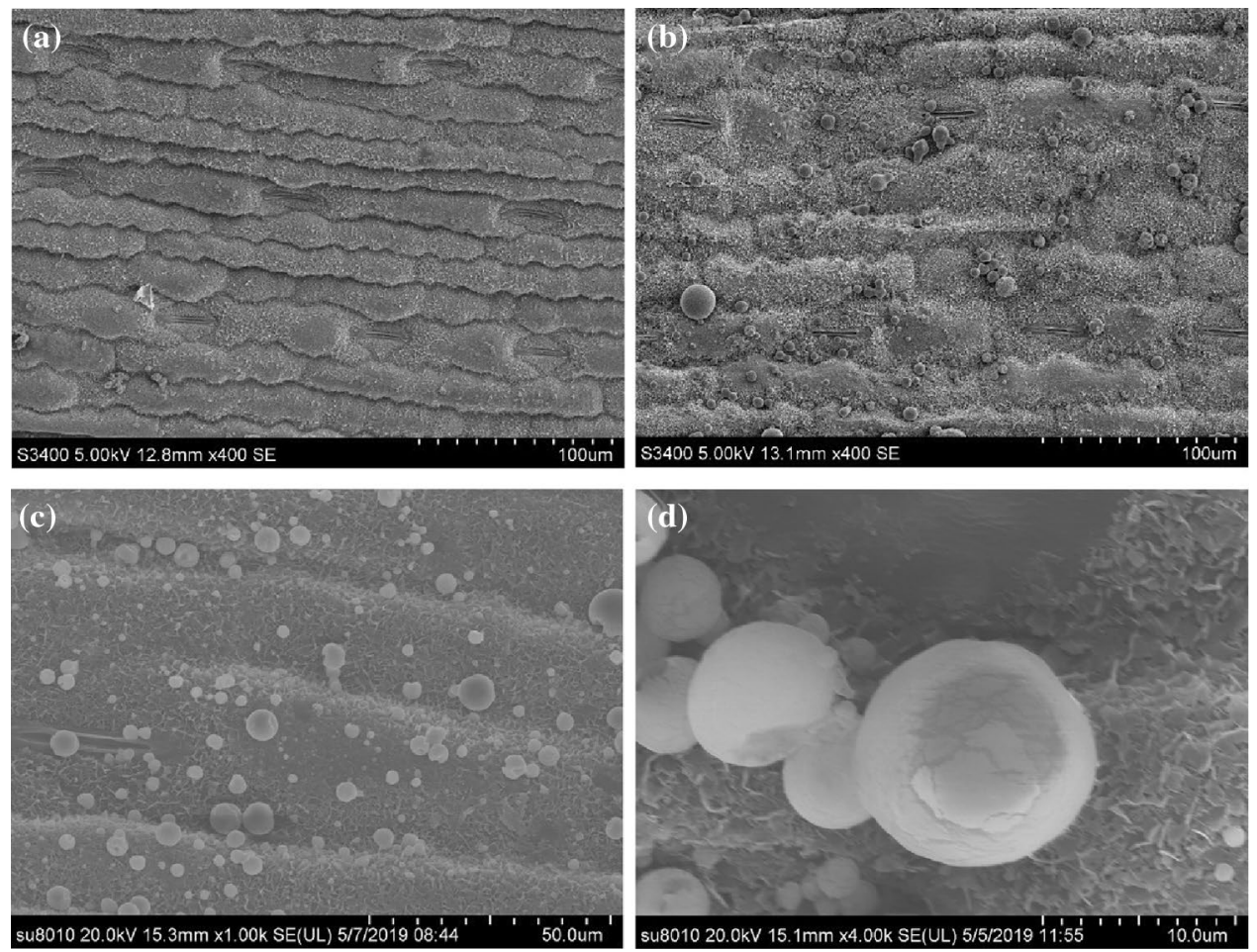

Figure 4. Stomata on a maize leaf. (a) shows stomata on the abaxial side; (b) shows stomata on the adaxial side; (c) magnified 1000 times of small spheres around the stomata of the adaxial leaf side; (d) magnified 1000 times of small spheres around the stomata of the adaxial leaf side.

content of MDA and EL, which may be related to the accumulation of $\mathrm{O}_{2}{ }^{--}$and $\mathrm{H}_{2} \mathrm{O}_{2}$, leading to damage to the biofilm system, and thus inhibiting the growth of seedlings (Table 2$)^{29}$. Si can affect the accumulation of ROS in plants, help maintain the balance of reactive oxygen metabolism, reduce membrane peroxidation, maintain the integrity of the membrane system, and enhance the activity of enzymes involved in the antioxidant system, thus promoting plant growth.

Stomatal size affects plant water-use efficiency, photosynthetic rate and yield ${ }^{37}$. The stomata control the exchange of water vapor and carbon dioxide between the blade's interior and the atmosphere. The adjustment of the stomatal aperture can affect the progress of photosynthesis in plants ${ }^{38}$. In this study, Si reduced the stomatal width and facilitates stomatal opening and closing (Table 5). These findings are consistent with those from Laza's research on rice ${ }^{39}$. Many small spheres with a metallic luster were found around the stomata on the adaxial side of leaves under the Si-60G treatment at a concentration of $15 \mathrm{~g} \cdot \mathrm{L}^{-1}$ (Fig. $4 \mathrm{~b}-\mathrm{d}$ ), compared with the stomata on the abaxial side (Fig. 4a). The element distribution on the surface of the sphere was subsequently analysed by energy dispersive spectrometry (EDS) (Fig. 5c). The distribution of the main elements on the surface of the spheres was shown (Fig. 5a), and many P elements were found on the surface of the spheres (Fig. 5b), which corroborates the findings of other researchers ${ }^{40,41}$. The P uptake of maize in response to Si fertilizer significantly increased, and there was a significant positive correlation between P uptake and Si uptake of maize. In the future, we need to further determine the route of $\mathrm{P}$ transport in maize and study the mechanism by which Si alleviates drought stress.

\section{Conclusion}

The present results showed that exogenous Si can improve the seed germination rate, germination potential, germination index and vigor index; promote seedling growth; and increased chlorophyll contents. In addition, Si could improve the antioxidant defence ability of maize plants and increase the contents of osmotic substances, thereby increasing the ability to remove ROS and maintain the integrity of the membrane system. Among the $\mathrm{Si}$ treatments, Si exerted the best positive effects at $15 \mathrm{~g} \cdot \mathrm{L}^{-1}$, while negative effects occurred in response to $25 \mathrm{~g} \cdot \mathrm{L}^{-1}$ (Si-60G) these findings indicate that the appropriate concentration of exogenous Si can promote maize seed germination and seedling growth laying a good foundation for subsequent growth.

\section{Materials and methods}

Plant material and treatments. This experiment was conducted in a controlled growth chamber at the Northeast Agricultural University of Harbin, Heilongjiang Province, China (45 448' 52" N, 126 43' 9" E). Exogenous Si compounds were provided by the school of Chemistry and Chemical Engineering, Harbin Institute of Technology. The characteristic features of Si preparation given in Table 6 and the particle size of Si preparation is shown in Fig. 6. The tested maize cultivar was Xianyu 335. Healthy, plump and pest-free maize seeds were sterilized for 20 min with $30 \%$ (w/v) hydrogen peroxide $\left(\mathrm{H}_{2} \mathrm{O}_{2}\right)$, and then repeatedly rinsed and soaked abundantly 

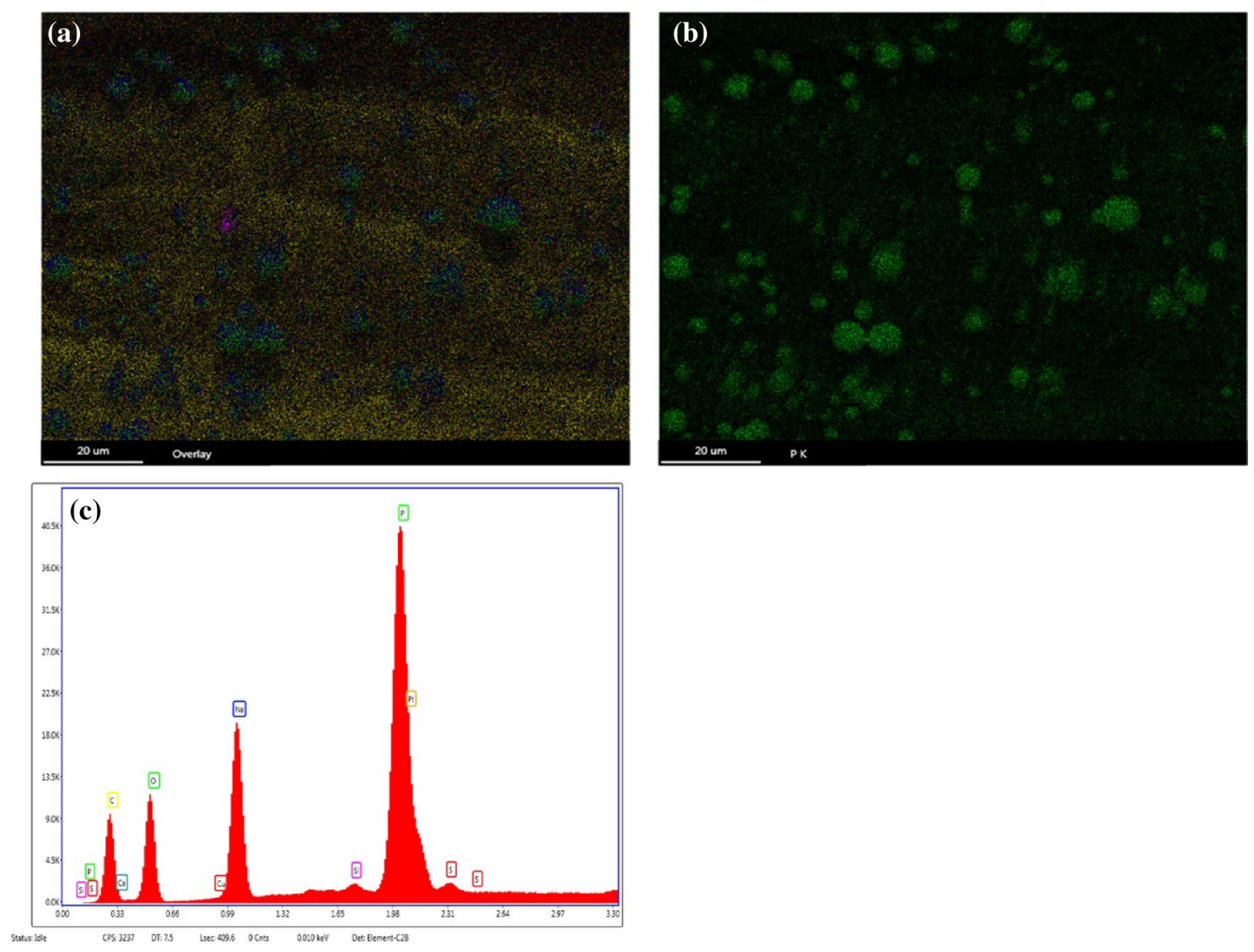

Figure 5. (a) shows the distribution of the main elements on the surface of the sphere; (b) shows the distribution of P; (c) shows the elements detected on the surface of the spheres by EDS.

\begin{tabular}{|l|l|l|}
\hline \multirow{2}{*}{ Properties } & Types & Si-60G \\
\cline { 2 - 3 } & Si-50G & 3-glyci doxypropyl trimethoxy silane \\
\hline Raw material & 3-aminopropyl triethoxy silane & Sol-gel process \\
\hline Preparation method & Sol-gel process & 9.42 \\
\hline $\mathrm{pH}$ & 5.95 & Irregular \\
\hline Morphology & Spherical & \\
\hline Average particle size & $323 \mathrm{~nm}$ & \\
\hline
\end{tabular}

Table 6. Physico-chemical properties of Si preparation.

\section{(a)}

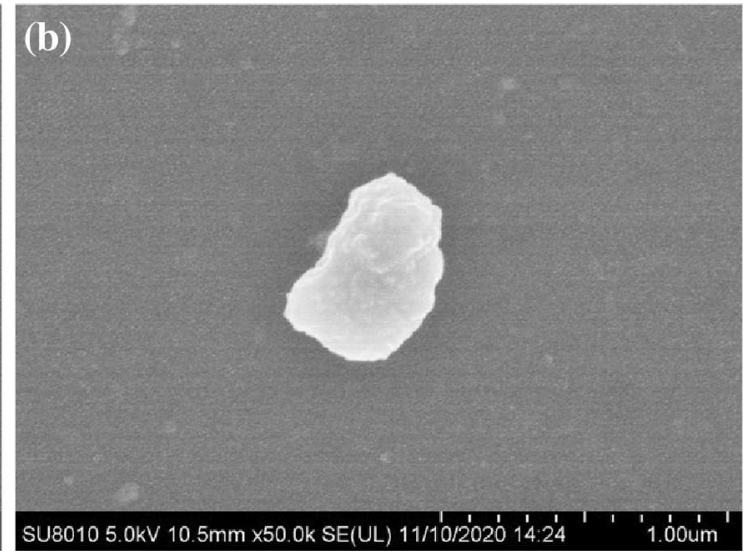

Figure 6. Scanning electron microscope images of Si preparation. (a) shows Si-50G. (b) shows Si-60G. 
with distilled water. Afterward, we wiped the water off the maize seeds surface with a filter and set the seeds aside. Five replicates (thirty seeds each) were placed on two layers of filter paper in $9 \mathrm{~cm}$ diameter petri dishes containing $15 \mathrm{~mL}$ of distilled water (control), and different concentration of exogenous $\mathrm{Si}(5,10,15,20$, and $25 \mathrm{~g} \cdot \mathrm{L}^{-1}$ ). The seeds were then allowed to germinate under the following environmental conditions: average day/ night temperature of $25 / 18^{\circ} \mathrm{C}$, relative humidity of $65 \pm 5 \%$, light intensity of $350 \mu \mathrm{mol} \cdot \mathrm{m}^{-2} \cdot \mathrm{s}^{-1}$ and photoperiod of $16 \mathrm{~h}$. To ensure the relative stability of each treatment concentration, the solution was supplemented once every $24 \mathrm{~h}$ and the number of maize seeds that germinated was recorded once every $24 \mathrm{~h}$.

After the germination (for 7 days), relatively uniform seedlings were selected and transferred to opaque plastic pots (inner diameter, $15.5 \mathrm{~cm}$; external diameter, $18 \mathrm{~cm}$; and height, $11 \mathrm{~cm}$ ) filled with $1.25 \mathrm{~kg}$ of soil per pot under the same environmental conditions as those reported above. The soil used in the experiment was black soil. The physical and chemical properties of the soil were as follows: $\mathrm{pH}, 8.06$; organic matter, $46.52 \mathrm{~g} \cdot \mathrm{kg}^{-1}$; total nitrogen, $3.58 \mathrm{~g} \cdot \mathrm{kg}^{-1}$; total phosphorus, $1.21 \mathrm{~g} \cdot \mathrm{kg}^{-1}$; total potassium, $182.7 \mathrm{mg} \cdot \mathrm{kg}^{-1}$; available phosphorus, $51.39 \mathrm{mg} \cdot \mathrm{kg}^{-1}$; available nitrogen, $144.90 \mathrm{mg} \cdot \mathrm{kg}^{-1}$; and $\mathrm{Si}, 78.8 \mathrm{mg} \cdot \mathrm{kg}^{-1}$. Maize seedlings at the three-leaf stage were used for the treatments with concentrations $\left(5,10,15,20\right.$ and $\left.25 \mathrm{~g} \cdot \mathrm{L}^{-1}\right)$ of Si and distilled water (control). The seedlings were sprayed once every 3 days, for a total of 2 times. Five millilitres was sprayed onto both sides of each leaf. Each treatment was repeated 4 times for a total of 44 pots.

Whole plants were sampled from each treatment on the 7th day for measurements of the growth parameters. The second fully developed leaves of the seedlings were removed on the 7th day for measurements of the growth parameters. The second fully developed leaves of the seedlings were removed on the 7 th day for scanning electron microscope observations and measuring the electrolyte leakage (EL). The remaining leaves were immediately frozen in liquid nitrogen and stored at $-80^{\circ} \mathrm{C}$ for subsequent determination of the other indicators ${ }^{42}$.

Measurements of germination. Seeds were considered to have germinated when the radicle extended for at least $2 \mathrm{~mm}$. After seven days of germination, the germination rate (GR), germination potential (GP), germination index (GI) and vigour index (VI) were measured according to following Eqs. ${ }^{10}$ :

$$
\mathrm{GR}=\mathrm{n} / \mathrm{N} \times 100 \%
$$

where, $\mathrm{n}$ is the number of germinated seeds and $\mathrm{N}$ represents the total number of seeds tested;

$$
\mathrm{GP}=\mathrm{a} / \mathrm{N} \times 100 \%
$$

where, $a$ is the number of germinated seeds after three days;

$$
\mathrm{GI}=\sum \mathrm{Gt} / \mathrm{Dt}
$$

where, Gt is the number of seeds germinated on $t$ days and Dt represents the corresponding day of germination; and

$$
\mathrm{VI}=\mathrm{GI} \times \text { mean of the dry weight of seedlings }
$$

Measurements of plant growth. The maize seedlings with their roots were collected and rinsed with tap water and distilled water. The maize seedlings were then separated into roots and shoots, which were weighted separately to determine the fresh weight (FW) of each part. The height of the shoots and the length of roots of each plant were simultaneously measured by ruler. Dry weight (DW) was measured after the samples had dried in an oven dried at $105^{\circ} \mathrm{C}$ for $30 \mathrm{~min}$ and had maintained constant weight at $80^{\circ} \mathrm{C}$ for $24 \mathrm{~h}$.

Measurements of pigment contents. Total chlorophyll, chlorophyll a (Chla), chlorophyll b $(\mathrm{Chl} b)$ and carotenoid (Car) compounds were extracted, after which their contents were measured and quantified according to modified method of Arnon ${ }^{43}$. After the extraction and analysis, the relative contents of Chl $a, C h l b$, Car and the total content of chlorophyll were calculated according the following formulae:

$$
\begin{gathered}
\text { Chl } a\left(\mathrm{mg} \cdot \mathrm{g}^{-1}\right)=\left[\left(12.71 \mathrm{~A}_{663}-2.59 \mathrm{~A}_{645}\right) \mathrm{V}\right] / \mathrm{W} \\
\operatorname{Chl} b\left(\mathrm{mg} \cdot \mathrm{g}^{-1}\right)=\left[\left(22.88 \mathrm{~A}_{645}-4.67 \mathrm{~A}_{663}\right) \mathrm{V}\right] / \mathrm{W} \\
\operatorname{Car}\left(\mathrm{mg} \cdot \mathrm{g}^{-1}\right)=(1000 \mathrm{~A} 470-3.27 \operatorname{Chl} a-104 C h l b) \mathrm{V} / 229 * \mathrm{~W} \\
\text { Total chlorophyll }\left(\mathrm{mg} \cdot \mathrm{g}^{-1}\right)=\left[\left(20.29 \mathrm{~A}_{645}+8.04 \mathrm{~A}_{663}\right) \mathrm{V}\right] / \mathrm{W}
\end{gathered}
$$

where, $\mathrm{V}$ represents final volume of chlorophyll extract in $80 \%$ acetone and $\mathrm{W}$ is $0.1 \mathrm{~g}$.

Measurement of osmoprotectants. The soluble sugar was quantified by the anthrone sulfuric acid method using $1 \%$ anthrone in concentrated $\mathrm{H}_{2} \mathrm{SO}_{4}$ as reagent ${ }^{44}$. Its absorbance was measured at $630 \mathrm{~nm}$, and a standard curve was plotted with $0 \sim 100 \mathrm{mg}$ of glucose.

The soluble protein was measured according to the coomassie brilliant blue G-250 method described by Bradford $^{45}$. Coomassie brilliant blue G-250 (100 mg) was dissolved in $50 \mathrm{~mL} 95 \%$ ethanol. Afterward, $100 \mathrm{~mL}$ 
$85 \%(\mathrm{w} / \mathrm{v})$ phosphoric acid was added to the solution. The resulting solution was diluted to a final volume of 1 $\mathrm{L}$. The reagent ultimately consisted of $0.01 \%(\mathrm{w} / \mathrm{v})$ coomassie brilliant blue G-250, $4.7 \%$ (w/v) ethanol, and $8.5 \%$ $(\mathrm{w} / \mathrm{v})$ phosphoric acid, and its absorbance was measured colorimetrically at $595 \mathrm{~nm}$.

Briefly, $100 \mathrm{mg}$ of tissue powder was homogenized in $10 \mathrm{~mL}$ of $3 \%$ aqueous sulfosalicylic acid for $10 \mathrm{~min}$ followed by filtration. Two milliliters of the filtrate, $2 \mathrm{~mL}$ of glacial acetic acid and $2 \mathrm{~mL}$ of acid ninhydrin were mixed together for $1 \mathrm{~h}$ at $90{ }^{\circ} \mathrm{C}$. The sample was extracted in $4 \mathrm{~mL}$ toluene and measured colourimetrically at $520 \mathrm{~nm}$ against toluene, and a standard curve with proline was used for the final calculations ${ }^{46}$.

Measurements of reactive oxygen species. First, $0.5 \mathrm{~mL}$ of the reaction mixture, $0.5 \mathrm{~mL}$ sulfanilic acid solution and $0.5 \mathrm{~mL}$ a-naphthylamine solution were mixed together and shaken evenly. After incubating at room temperature for $20 \mathrm{~min}$, the optical density of the mixture was determined at $530 \mathrm{~nm}$ via a spectrophotometer ${ }^{47}$.

$\mathrm{H}_{2} \mathrm{O}_{2}$ was extracted by homogenizing $0.3 \mathrm{~g}$ leaf tissue with $3 \mathrm{~mL}$ of $50 \mathrm{mM}$ phosphate buffer ( $\mathrm{pH}$ 6.5) together. The homogenate was centrifuged at $6000 \mathrm{rpm}$ for $25 \mathrm{~min}$. The supernatant was brought up to $3 \mathrm{~mL}$ with the phosphate buffer. To determine $\mathrm{H}_{2} \mathrm{O}_{2}$ content, $3 \mathrm{~mL}$ of extracted solution was mixed with $1 \mathrm{~mL}$ of $0.1 \%$ titanium sulphate in $20 \% \mathrm{H}_{2} \mathrm{SO}_{4}(\mathrm{v} / \mathrm{v})$ were mixed together, after which the mixture was then centrifuged at $6,000 \mathrm{rpm}$ for $15 \mathrm{~min}$. The intensity of the yellow color of the supernatant was measured at $410 \mathrm{~nm}$. The $\mathrm{H}_{2} \mathrm{O}_{2}$ content was calculated from a standard curve prepared via hydrogen peroxide of known strength ${ }^{48}$.

Measurements of lipid peroxidation. Plant samples $(0.4 \mathrm{~g})$ were homogenized with $2.4 \mathrm{~mL} 0.1 \%$ trichloroacetic acid (TCA) and the homogenates were centrifuged at $12,000 \mathrm{rpm}$ for $15 \mathrm{~min}$. The supernatant $(0.5 \mathrm{~mL})$ and $20 \%$ TCA $1: 1(\mathrm{v} / \mathrm{v})$ were containing $0.5 \%(\mathrm{w} / \mathrm{v})$ thiobarbituric acid (TBA) were mixed together $(1: 1)$, after which the solution was heated at $100{ }^{\circ} \mathrm{C}$ for $20 \mathrm{~min}$. The absorbance was subsequently determined at 450,532 , and $600 \mathrm{~nm}^{25,49}$.

EL was used to evaluate plasma membrane permeability and measured using an electrical conductivity meter (DDS-307A, Inasa Analytical Instrument Co., Ltd., Shanghai, P. R. China). Each $0.5 \mathrm{~g}$ of fresh leaf material of maize seedling was placed in individual stoppered triangular flasks containing $10 \mathrm{~mL}$ of deionized water. The samples were incubated at $25^{\circ} \mathrm{C}$ for $24 \mathrm{~h}$. The electrical conductivity of the solution $\left(\mathrm{S}_{1}\right)$ was measured after incubation. The samples were then placed in a boiling water bath for $10 \mathrm{~min}$ and the second measurement $\left(\mathrm{S}_{2}\right)$ was determined after the solutions cooled to room temperature. $E L=S_{1} / S_{2} \times 100 \%{ }^{50}$.

Measurements of antioxidants. Crude enzyme extracts were prepared according to the method described by Pan et al. ${ }^{51}$. A total of $0.5 \mathrm{~g}$ of frozen leaf samples from maize seedlings were ground to a fine powder with liquid nitrogen using a chilled mortar and pestle and then homogenized in $5 \mathrm{~mL}$ extraction buffer containing of $50 \mathrm{mM}$ phosphate buffer ( $\mathrm{pH} 7.8$ ), $0.1 \mathrm{mM}$ ethylenediaminetetraacetic acid (EDTA), $0.3 \%(\mathrm{v} / \mathrm{v}$ ) Triton X-100, and 4\% gpolyvinylpyrrolidone (PVP). The homogenate was then immediately centrifuged for $20 \mathrm{~min}$ at $12,000 \mathrm{rpm}$. Phosphate buffer was subsequently added to the supernatant, which was used to analyse the activity of antioxidant enzymes. All operations were carried out at $0-4{ }^{\circ} \mathrm{C}$.

Superoxide (SOD) activity was measured according to its ability to inhibit the photochemical reduction of nitro blue tetrazolium (NBT), which was recorded at $560 \mathrm{~nm}$. One unit of SOD was defined as the amount of enzyme that inhibited NBT reduction by $50 \%{ }^{52}$.

Catalase (CAT) activity was measured according to its ability to consume the amount of $\mathrm{H}_{2} \mathrm{O}_{2}{ }^{53}$. The CAT reaction solution comprised $50 \mathrm{mM}$ phosphate buffer $(\mathrm{pH} 7.8), 0.1 \mathrm{M} \mathrm{H}_{2} \mathrm{O}_{2}$ and $0.1 \mathrm{~mL}$ enzyme extract. Changes in the absorbance of the reaction solution at $240 \mathrm{~nm}$ were recorded for $5 \mathrm{~min}$. One unit of CAT activity was defined as the absorbance change of 0.01 units per minute.

Peroxidase (POD) activity was determined using guaiacol as the substrate and assayed according to the method of Zheng et al. ${ }^{54}$ with minor modifications. First, $0.2 \mathrm{~mL}$ of the enzyme extract, $2 \mathrm{~mL}$ of $10 \mathrm{mM} \mathrm{Na}$ phosphate buffer ( $\mathrm{pH} 7.4), 0.1 \mathrm{~mL}$ of $1 \%$ guaiacol $(\mathrm{v} / \mathrm{v})$, and $0.1 \mathrm{~mL} 0.3 \% \mathrm{H}_{2} \mathrm{O}_{2}(\mathrm{v} / \mathrm{v})$ were mixed together, after which the homogenates were centrifuged at $14,000 \mathrm{rpm}$ for $20 \mathrm{~min}$. The change in absorbance was measured at $470 \mathrm{~nm}$ for $5 \mathrm{~min}$ via a UV-visible spectrophotometer (T6, Persee, Beijing, P. R. China). One unit of POD activity was defined as an absorbance change of 0.01 units per minute.

In total, $0.5 \mathrm{~g}$ of seedling tissue was homogenized at $4{ }^{\circ} \mathrm{C}$ in $1 \mathrm{~mL}$ of extraction buffer $[50 \mathrm{mM}$ potassium phosphate buffer ( $\mathrm{pH} 7.0$ ), 1\% Triton X-100, and $7 \mathrm{mM} 2$-mercaptoethanol] with mortar and pestle. The homogenate was then centrifuged at 25,000 rpm for $20 \mathrm{~min}$, after which the supernatant was used as the crude extract for the ascorbate peroxidase (APX) and glutathione reductase (GR) assay ${ }^{55}$.

A $3 \mathrm{~mL}$ reaction mixture was composed of $50 \mathrm{mM}$ phosphate buffer ( $\mathrm{pH}$ 7.0) that consisted of $0.1 \mathrm{mM}$ EDTA, $0.3 \mathrm{mM}$ ascorbic acid (AsA), $0.06 \mathrm{mM} \mathrm{H}_{2} \mathrm{O}_{2}$ and $0.2 \mathrm{~mL}$ of enzyme extract. The homogenate was then centrifuged at $10,000 \mathrm{rpm}$ for $20 \mathrm{~min}$. The oxidation of ascorbate was followed by the decrease in the absorbance at $240 \mathrm{~nm}^{55}$.

GR activity was assayed by measuring the decrease in absorbance at $340 \mathrm{~nm}$ due to the oxidation of reduced nicotinamide adenine dinucleotide phosphate $(\mathrm{NADPH})^{55}$. A $3 \mathrm{~mL}$ reaction mixture comprised $50 \mathrm{mM}$ phosphate buffer ( $\mathrm{pH}$ 8.2) that consisted of $1 \mathrm{mM}$ EDTA, $0.2 \mathrm{mM}$ NADPH, $1 \mathrm{mM}$ oxidized glutathione (GSSG) and $0.2 \mathrm{~mL}$ of enzyme extract.AsA content was determined according to the method of Li et al. ${ }^{56}$ with minor modifications. Standards for AsA were prepared in the range of $0 \sim 60 \mu \mathrm{g}$ in $1 \mathrm{~mL}$ of $5 \%(\mathrm{w} / \mathrm{v}) \mathrm{TCA}, 1 \mathrm{~mL}$ alcohol, $0.5 \mathrm{~mL} 0.4 \% \mathrm{H}_{3} \mathrm{PO}_{4}$-alcohol, $1 \mathrm{~mL}$ of $0.5 \%$ bathophenanthroline (BP)-alcohol and $0.5 \mathrm{~mL}$ of $0.03 \% \mathrm{FeCl}_{3}$-alcohol at $30{ }^{\circ} \mathrm{C}$ for $60 \mathrm{~min}$ and measured at $534 \mathrm{~nm}$. One gram of leaf tissue was ground in a chilled mortar and pestle in $5 \mathrm{~mL}$ of $5 \%(\mathrm{w} / \mathrm{v}) \mathrm{TCA}$. The homogenates were centrifuged at $4000 \mathrm{rpm}$ for $10 \mathrm{~min}$ at $4{ }^{\circ} \mathrm{C}$. The supernatant $(1 \mathrm{~mL})$ and $1 \mathrm{~mL}$ of $5 \%(\mathrm{w} / \mathrm{v})$ TCA were mixed together according to the method of generating a standard curve. For each sample the AsA content was estimated as described above. To determine the reduced glutathione (GSH) content, $0.1 \mathrm{~g}$ frozen leaf tissue was ground in a chilled mortar and pestle with $3 \mathrm{~mL}$ of $5 \%(\mathrm{v} / \mathrm{v})$ TCA. 

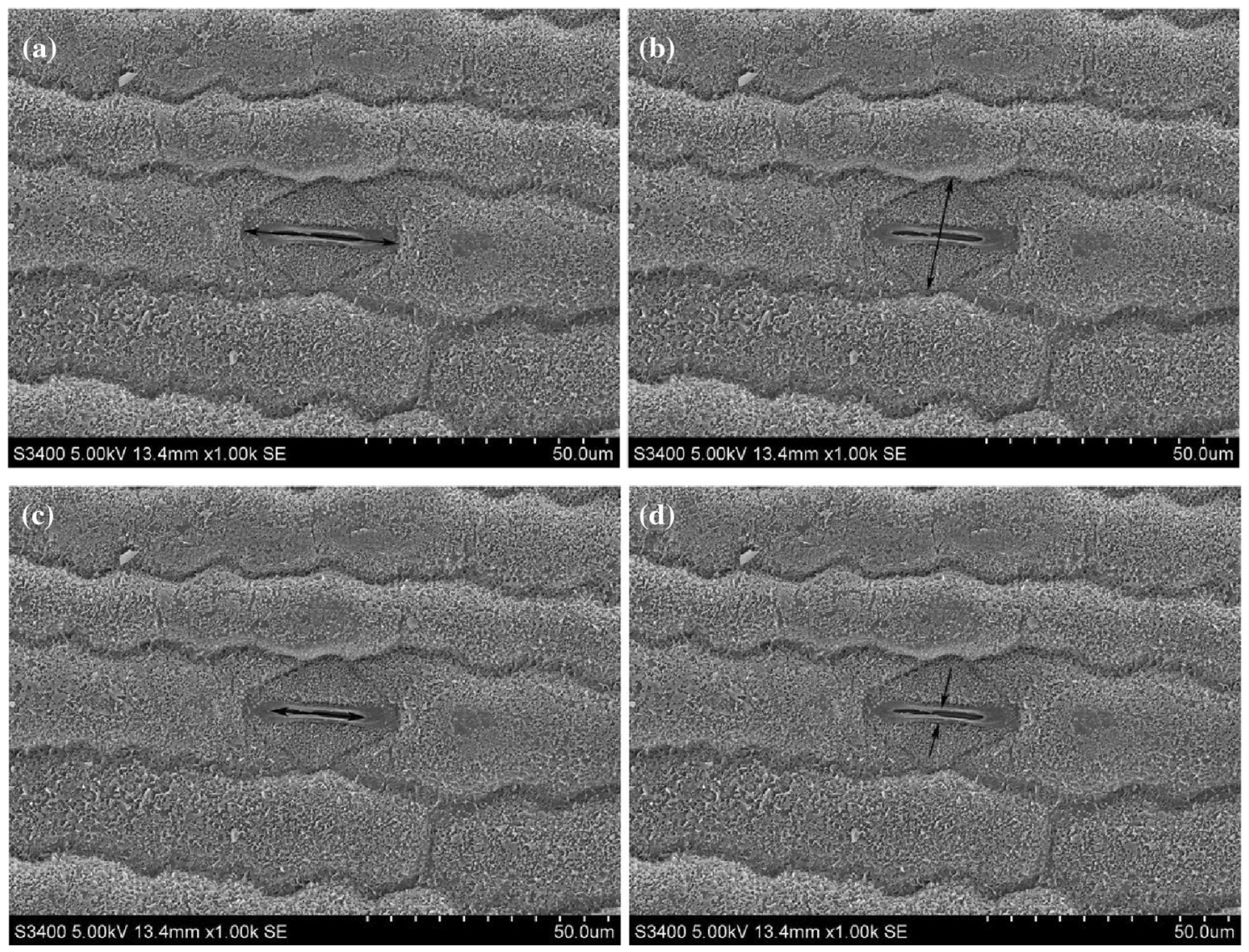

Figure 7. Measurement of stomatal length (a), width (b), aperture length (c) and width (d).

The homogenates were subsequently centrifuged at $2500 \mathrm{rpm}$ for $15 \mathrm{~min}$ at $4{ }^{\circ} \mathrm{C}$. The supernatants were then analyzed for their content of $\mathrm{GSH}^{57}$. Changes in absorbance of the reaction mixture were measured at $420 \mathrm{~nm}$.

Measurement of Si content. Si content of maize seedlings was determined colorimetrically by the molybdate blue method and the absorbance was observed at $630 \mathrm{~nm}$. Different amounts of silicic acid were included as standards for determining Si content of plant samples ${ }^{25}$.

Scanning electron microscopy-based measurements of the stomata. The leaf samples were cut into pieces of approximately $2 \times 5 \mathrm{~mm}$ in size and fixed for more than $1.5 \mathrm{~h}$ with $2.5 \%$ glutaraldehyde in $0.1 \mathrm{M}$ phosphate-buffered saline (PBS; $\mathrm{pH}$ 6.8) solution. The fixed samples were washed three times with the same solution for $10 \mathrm{~min}$ each. Afterward, the samples were dehydrated one time in a graded ethanol series $(50 \%, 70 \%$, and $90 \%$ ) and two times in absolute ethanol for $10 \mathrm{~min}$. The samples were displaced miscible liquids (comprising a 1:1 mixture of tertiary butanol and absolute ethyl alcohol) and absolute ethyl tertiary butanol for $15 \mathrm{~min}$. The samples were maintained at $-20^{\circ} \mathrm{C}$ for $30 \mathrm{~min}$ and dried in a freeze-drier (ES-2030, Hitachi, Tokyo, Japan) for $4 \mathrm{~h}$. The observed samples faced up and were adhered to the scanning electron microscope sample table with conductive tape. The sample surfaces were coated with 100-150 A metal films by ion sputter (E-1010, Hitachi, Tokyo, Japan). The sections were mounted on the sample table, observed with a scanning electron microscope and imaged(S-3400N, Hitachi, Tokyo, Japan).

The size and aperture of stomata $(n=20)$ in the center of the lower epidermis of the second fully expanded leaf from the top of four plants in each treatment were observed and imaged via a scanning electron microscopy at $2000 \times$ magnification (Fig. 7).

Statistical analysis. The data were recorded and processed using Excel 2010 (Microsoft Inc., WA, Redmond, USA) and SPSS 19.0 software (SPSS Inc., Chicago, IL, USA). The variance and significance of the data were analysed. To detect significance differences between the means, Duncan's multiple range test was performed at a significance level of $\mathrm{P}<0.05^{58}$.

\section{Data availability}

The datasets generated during and/or analyzed during the current study are available from the corresponding author on reasonable request. 
Received: 21 January 2020; Accepted: 10 December 2020

Published online: 13 January 2021

\section{References}

1. Song, H., Li, Y., Zhou, L., Xu, Z. \& Zhou, G. Maize leaf functional responses to drought episode and rewatering. Agric. For. Meteorol. 249, 57-70 (2018).

2. Li, L. J. et al. Effect of DCPTA seeding on seed germination and root growth of maize in cold region. Crop Mag. 04, 152-156 (2015).

3. Li, M., Liu, X. \& Tao, B. Effect of protective agent soaker on germination of maize seeds and their physiological properties. J. Northeast Agric. Univ. 39, 21-24 (2008).

4. Epstein, E. The anomaly of silicon in plant biology. Proc. Natl. Acad. Sci. 91(1), 11-17 (1994).

5. Rahman, M. F., Ghosal, A., Alam, M. F. \& Kabir, A. H. Remediation of cadmium toxicity in field peas (Pisum sativum L.) through exogenous silicon. Ecotoxicol. Environ. Saf. 135, 165-172 (2017).

6. Yan, G. C., Nikolic, M., Ye, M. J., Xiao, Z. X. \& Liang, Y. C. Silicon acquisition and accumulation in plant and its significance for agriculture. J. Integr. Agric. 17(10), 2138-2150 (2018).

7. Artyszak, A. Effect of silicon fertilization on crop yield quantity and quality-a literature review in Europe. Plants. 7(3), 54 (2018).

8. Shi, Y. et al. Silicon improves seed germination and alleviates oxidative stress of bud seedlings in tomato under water deficit stress. Plant Physiol. Biochem. 78, 27-36 (2014).

9. Dong, W., Ma, H. \& Ma, T. Effects of exogenous silicon on Loium perenne seed germination and seedlings physiological characteristics under stress conditions. J. Gansu Agric. Univ. 52(6), 90-96 (2017).

10. Biju, S., Fuentes, S. \& Gupta, D. Silicon improves seed germination and alleviates drought stress in lentil crops by regulating osmolytes, hydrolytic enzymes and antioxidant defense system. Plant Physiol. Biochem. 119, 250-264 (2017).

11. Zhu, Y. \& Gong, H. Beneficial effects of silicon on salt and drought tolerance in plants. Agron. Sustain. Dev. 34(2), 455-472 (2013).

12. Meng, J., Cui, L., Han, J. W. \& Zhang, M. Advances in studies on the level of soil silicon and the effect of vegetable application. Anhui Agric. Sci. Bull. 19(17), 63-66 (2013).

13. Ren, H. et al. Dynamic effect of foliar application of different silicon compounds on rice nutrient absorption. J. Jilin Agric. Univ. 39(05), 596-602 (2017).

14. Sun, Y. K. et al. Regulating effect of exogenous silicon on soil fertility in paddy fields. J. Northeast Agric. Univ. (Engl. Ed). 27(02), 33-36 (2020).

15. Zhang, F., Lei, G., Zhang, P. \& Sun, C. Effects of salicylic acid on the germination of velvetbean seeds and physiological characteristics of velvetbean seedlings under cold stress. J. Northwest A \& F Univ. (Nat. Sci. Ed). 40(4), 205-216 (2012).

16. Lee, S. K., Sohn, E. Y., Hamayun, M., Yoon, J. Y. \& Lee, I. J. Effect of silicon on growth and salinity stress of soybean plant grown under hydroponic system. Agrofor. Syst. 80(3), 333-340 (2010).

17. Ali, S. et al. The influence of silicon on barley growth, photosynthesis and ultra-structure under chromium stress. Ecotoxicol. Environ. Saf. 89, 66-72 (2013).

18. Melkozernov, A. N. \& Blankenship, R. E. In Photosynthetic functions of chlorophylls (ed. Scheer, H.) $397-412$ (Springer, Berlin, 2006).

19. Song, A. L., Li, P., Li, Z. J. \& Liang, Y. C. Effects of silicon on photosynthesis and related physiological characteristics of Chinese cabbage under cadmium stress. Acta Horticult. Sin. 38(09), 1675-1684 (2011).

20. Sun, D. Q. et al. Research progress of silica nanoparticle effects on the growth and development of plants. Chin. J. Trop. Crops. 40(11), 2300-2311 (2019).

21. Guo, X., Guo, F., Liu, Z. \& Hao, S. Effects of water stress and rewatering on photosynthetic rate and soluble sugar of maize. J. Maize Sci. 16(6), 68-70 (2008).

22. Silva, E. N., Ferreira-Silva, S. L., Viégas, R. A. \& Silveira, J. A. G. The role of organic and inorganic solutes in the osmotic adjustment of drought-stressed Jatropha curcas plants. Environ. Exp. Bot. 69, 279-285 (2010).

23. Singh, M., Singh, V. P. \& Prasad, S. M. Responses of photosynthesis, nitrogen and proline metabolism to salinity stress in Solanum lycopersicum under different level of nitrate supplementation. Plant Physiol. Biochem. 109, 72-83 (2016).

24. Crusciol, C. A., Pulz, A. L., Lemos, L. B., Soratto, R. P. \& Lima, G. P. Effects of silicon and drought stress on tuber yield and leaf biochemical characteristics in potato. Crop Sci. 49(3), 949-954 (2009).

25. Zhang, W. J. et al. Silicon alleviates salt and drought stress of Glycyrrhiza uralensis seedling by altering antioxidant metabolism and osmotic adjustment. J. Plant. Res. 130(3), 611-624 (2017).

26. Chutipaijit, S. Changes in physiological and antioxidant activity of indica rice seedlings in response to mannitol-induced osmotic stress. Chil. J. Agric. Res. 76(4), 455-462 (2016).

27. Henricks, P. A. \& Nijkamp, F. P. Reactive oxygen species as mediators in asthma. Pulm. Pharmacol. Ther. 14(6), 409-421 (2001).

28. Siedlinski, M., Van Diemen, C. C., Postma, D. S., Vonk, J. M. \& Boezen, H. M. Superoxide dismutases, lung function and bronchial responsiveness in a general population. Eur. Respir. J. 33(5), 986-992 (2009).

29. Gill, S. S. \& Tuteja, N. Reactive oxygen species and antioxidant machinery in abiotic stress tolerance in crop plants. Plant Physiol. Biochem. 48(12), 909-930 (2010).

30. Song, X. H. et al. Seed dressing with thiacloprid affects physiological and biochemical indexes of maize seedling. Chin. Agric. Sci. Bull. 34(4), 118-122 (2018).

31. Li, M., Liu, X. R. \& Tao, B. Effects of protective agent soaker on germination of maize seeds and their physiological properties. J. Northeast Agric. Univ. 39(9), 21-24 (2008).

32. Lu, S. C. Regulation of glutathione synthesis. Mol. Aspects Med. 30, 42-59 (2009).

33. Noctor, G., Mhamdi, A. \& Foyer, C. H. The roles of reactive oxygen metabolism in drought: not so cut and dried. Plant Physiol. 164(4), 1636-1648 (2014).

34. Yang, H., Wu, F. \& Cheng, J. Reduced chilling injury in cucumber by nitric oxide and the antioxidant response. Food Chem. 127(3), 1237-1242 (2011).

35. Mo, Y. et al. Regulation of plant growth, photosynthesis, antioxidation and osmosis by an arbuscular mycorrhizal fungus in watermelon seedlings under well-watered and drought conditions. Front. Plant Sci. 7, 644 (2016).

36. Ahmad, A. et al. Synergistic effects of nitric oxide and silicon on promoting plant growth, oxidative stress tolerance and reduction of arsenic uptake in Brassica juncea. Chemosphere 262, 128384 (2020).

37. Wang, S. G. et al. Mapping QTLs for stomatal density and size under drought stress in wheat (Triticum aestivum L.). J. Integr. Agric. 15(9), 1955-1967 (2016).

38. Hetherington, A. M. \& Woodward, F. I. The role of stomata in sensing and driving environmental change. Nature 424, $901-908$ (2003).

39. Laza, M. R. C., Kondo, M., Ideta, O., Barlaan, E. \& Imbe, T. Quantitative trait loci for stomatal density and size in lowland rice. Euphytica 172(2), 149-158 (2010).

40. Neu, S., Schaller, J. \& Dudel, E. G. Silicon availability modifies nutrient use efficiency and content, C:N:P stoichiometry, and productivity of winter wheat (Triticum aestivum L.). Sci. Rep. 7, 40829 (2017).

41. Kostic, L., Nikolic, N., Bosnic, D., Samardzic, J. \& Nikolic, M. Silicon increases phosphorus (P) uptake by wheat under low P acid soil conditions. Plant Soil 419, 447-455 (2017). 
42. Xie, T. et al. Modulating the antioxidant system by exogenous 2-(3,4-dichlorophenoxy) triethylamine in maize seedlings exposed to polyethylene glycol-simulateddroughtstress. PLOS ONE 13(9), e0203626 (2018).

43. Arnon, D. I. Copper enzymes in isolated chloroplasts. Polyphenoloxidase in beta vulgaris. Plant Physiol. 24, 1 (1949).

44. Loutfy, N. et al. Changes in the water status and osmotic solute contents in response to drought and salicylic acid treatments in four different cultivars of wheat (Triticum aestivum). J. Plant. Res. 125(1), 173-184 (2012).

45. Bradford, M. M. A rapid and sensitive method for the quantitation of microgram quantities of protein utilizing the principle of protein-dye binding. Anal. Biochem. 72, 248-254 (1976).

46. Bates, L. S., Waldren, R. P. \& Teare, I. D. Rapid determination of free proline for water-stress studies. Plant Soil 39(1), 205-207 (1973).

47. Elstner, E. F. \& Heupel, A. Inhibition of nitrite formation from hydroxylammoniumchloride: A simple assay for superoxide dismutase. Anal. Biochem. 70(2), 616-620 (1976).

48. Jana, S. \& Choudhuri, M. A. Glycolate metabolism of three submersed aquatic angiosperms during ageing. Aquat. Bot. 12, 345-354 (1982).

49. Zicari, M. A., d'Aquino, L., Paradiso, A., Mastrolitti, S. \& Tommasi, F. Effect of cerium on growth and antioxidant metabolism of Lemna minor L. Ecotoxicol. Environ. Saf. 163, 536-543 (2018).

50. Shen, X. et al. Silicon effects on photosynthesis and antioxidant parameters of soybean seedlings under drought and ultraviolet-B radiation. J. Plant Physiol. 167(15), 1248-1252 (2010).

51. Pan, Y., Wu, L. J. \& Yu, Z. L. Effect of salt and drought stress on antioxidant enzymes activities and SOD isoenzymes of liquorice (Glycyrrhiza uralensis Fisch). Plant Growth Regul. 49, 157-165 (2006).

52. Zhang, X. et al. Effect of silicon on seed germination and the physiological characteristics of G7lycyrrhizauralensis under different levels of salinity. J. Hortic. Sci. Biotechnol. 90(4), 439-443 (2015).

53. Sohn, Y. G., Lee, B. H., Kang, K. Y. \& Lee, J. J. Effects of $\mathrm{NaCl}$ stress on germination, antioxidant responses, and proline content in two rice cultivars. J. Plant Biol. 48(2), 201-208 (2005).

54. Zheng, X. \& Van Huystee, R. B. Peroxidase-regulated elongation of segments from peanut hypocotyls. Plant Sci. 81(1), 47-56 (1992).

55. Kang, H. M. \& Saltveit, M. E. Activity of enzymatic antioxidant defense systems in chilled and heat shocked cucumber seedling radicles. Physiol. Plant. 113(4), 548-556 (2001).

56. Li, H., Zhu, Y., Hu, Y., Han, W. \& Gong, H. Beneficial effects of silicon in alleviating salinity stress of tomato seedlings grown under sand culture. Acta Physiol. Plant. 37(4), 71 (2015).

57. Khan, A. L., Waqas, M., Hussain, J., Al-Harrasi, A. \& Lee, I. J. Fungal endophyte Penicillium janthinellum LK5 can reduce cadmium toxicity in Solanum lycopersicum (Sitiens and Rhe). Biol. Fertil. Soils 50(1), 75-85 (2014).

58. Wang, C. et al. Biphasic effects of lanthanum on Vicia faba L. seedlings under cadmium stress, implicating finite antuoxidation and potential ecological risk. Chemosphere 86(5), 530-537 (2012).

\section{Acknowledgements}

This publication was supported by the project of Open Research Fund of China Meteorological Administration (stqx2018zd01) and the national science and technology innovation project to increase grain yield and efficiency of China (2018YFD0300103-1).

\section{Author contributions}

Y.S. and H.R. conceived the study. X.M., X.L. and W.L conducted the experiments and analyzed the data. J.X. led the writing of the manuscript and everyone participated in editing the manuscript.

\section{Competing interests}

The authors declare no competing interests.

\section{Additional information}

Correspondence and requests for materials should be addressed to H.R.

Reprints and permissions information is available at www.nature.com/reprints.

Publisher's note Springer Nature remains neutral with regard to jurisdictional claims in published maps and institutional affiliations.

(c) (i)

Open Access This article is licensed under a Creative Commons Attribution 4.0 International License, which permits use, sharing, adaptation, distribution and reproduction in any medium or format, as long as you give appropriate credit to the original author(s) and the source, provide a link to the Creative Commons licence, and indicate if changes were made. The images or other third party material in this article are included in the article's Creative Commons licence, unless indicated otherwise in a credit line to the material. If material is not included in the article's Creative Commons licence and your intended use is not permitted by statutory regulation or exceeds the permitted use, you will need to obtain permission directly from the copyright holder. To view a copy of this licence, visit http://creativecommons.org/licenses/by/4.0/.

(c) The Author(s) 2021 